\title{
Modern Development and Production of a New Live Attenuated Bacterial Vaccine, SCHU S4 $\Delta c l p B$, to Prevent Tularemia
}

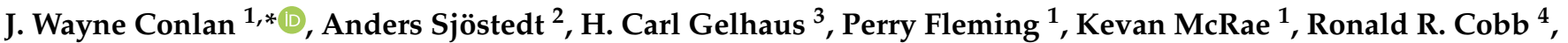 \\ Roberto De Pascalis ${ }^{5,+}$ and Karen L. Elkins ${ }^{5,+}$
}

\section{check for} updates

Citation: Conlan, J.W.; Sjöstedt, A.; Gelhaus, H.C.; Fleming, P.; McRae, K.; Cobb, R.R.; De Pascalis, R.; Elkins, K.L. Modern Development and Production of a New Live Attenuated Bacterial Vaccine, SCHU S4 $\Delta c l p B$, to Prevent Tularemia. Pathogens 2021, 10 795. https://doi.org/10.3390/ pathogens 10070795

Academic Editors: Douglas S. Reed Karsten Hazlett and Eileen Barry

Received: 27 May 2021

Accepted: 20 June 2021

Published: 23 June 2021

Publisher's Note: MDPI stays neutral with regard to jurisdictional claims in published maps and institutional affiliations.

Copyright: (C) 2021 by the authors. Licensee MDPI, Basel, Switzerland. This article is an open access article distributed under the terms and conditions of the Creative Commons Attribution (CC BY) license (https:// creativecommons.org/licenses/by/ $4.0 /)$
1 Department of Human Health and Therapeutics, National Research Council-Canada, Ottawa, ON K1A 0R6, Canada; perry.fleming@nrc-cnrc.gc.ca (P.F.); kevan.mcrae@nrc-cnrc.gc.ca (K.M.)

2 Laboratory for Molecular Infection Medicine Sweden (MIMS), Department of Clinical Microbiology, Umeå University, SE-901 85 Umeå, Sweden; anders.sjostedt@climi.umu.se

MRIGlobal, Kansas City, MO 64110, USA; cgelhaus@mriglobal.org

4 Ology Bioservices Inc., Alachua, FL 32615, USA; ron.cobb@resilience.com

5 US Food and Drug Administration, Center for Biologics Evaluation and Research, Silver Spring, MD 20993, USA; roberto.depascalis@fda.hhs.gov (R.D.P.); karen.elkins@fda.hhs.gov (K.L.E.)

* Correspondence: wayne.conlan@nrc-cnrc.gc.ca; Tel.: +1-613-229-5326

+ Disclaimer: Contributions from Dr. Elkins and Dr. De Pascalis are an informal communication and represent the authors' own best judgement. These comments do not bind or obligate FDA.

Abstract: Inhalation of small numbers of Francisella tularensis subspecies tularensis (Ftt) in the form of small particle aerosols causes severe morbidity and mortality in people and many animal species. For this reason, Ftt was developed into a bona fide biological weapon by the USA, by the former USSR, and their respective allies during the previous century. Although such weapons were never deployed, the 9/11 attack quickly followed by the Amerithrax attack led the U.S. government to seek novel countermeasures against a select group of pathogens, including Ftt. Between 2005-2009, we pursued a novel live vaccine against Ftt by deleting putative virulence genes from a fully virulent strain of the pathogen, SCHU S4. These mutants were screened in a mouse model, in which the vaccine candidates were first administered intradermally (ID) to determine their degree of attenuation. Subsequently, mice that survived a high dose ID inoculation were challenged by aerosol or intranasally (IN) with virulent strains of Ftt. We used the current unlicensed live vaccine strain (LVS), first discovered over 70 years ago, as a comparator in the same model. After screening 60 mutants, we found only one, SCHU S4 $\triangle c l p B$, that outperformed LVS in the mouse ID vaccinationrespiratory-challenge model. Currently, SCHU S4 $\Delta c l p B$ has been manufactured under current good manufacturing practice conditions, and tested for safety and efficacy in mice, rats, and macaques. The steps necessary for advancing SCHU S4 $\Delta c l p B$ to this late stage of development are detailed herein. These include developing a body of data supporting the attenuation of SCHU S4 $\triangle c l p B$ to a degree sufficient for removal from the U.S. Select Agent list and for human use; optimizing SCHU $\mathrm{S} 4 \Delta c l p B$ vaccine production, scale up, and long-term storage; and developing appropriate quality control testing approaches.

Keywords: tularemia; Francisella tularensis; live attenuated vaccine; product development

\section{Introduction}

Tularemia is the generic term for a spectrum of infectious diseases caused by the facultative intracellular bacterium, Francisella tularensis subspecies tularensis (Ftt), or F. tularensis subspecies holarctica $(F t h)$ [1,2]. Ftt is only found in North America, while Fth is found throughout the Northern hemisphere. Tularemia is uncommon in the USA, but certain European countries and especially Sweden experience hundreds to thousands of cases of Fth infection annually [3,4]. Disease symptoms range from local eschar formation and 
lymphadenopathy, to high mortality following fulminant systemic infection that disseminates to lungs, liver, spleen, and blood, particularly after inhalation of $F t t$ small particle aerosols [5].

Although Francisella infects a wide range of animals as well as humans [1], no cases of human-to-human transmission have ever been convincingly documented. Nonetheless, despite the lack of contagiousness, Ftt's virulence made it a primary target for bioweapon development between the 1940s and 1980s [2,6,7]. To counter the threat of biowarfare using $F t t$, beginning in the 1940s, several vaccines were developed, ranging from so-called "Foshay" killed bacterial vaccines to the live vaccine strain (LVS) developed in the USA from live attenuated strains used in the USSR [8-10]. Non-human primate (NHP) experiments, field observations, and human vaccination and challenge studies have suggested that both killed and live vaccines protected against dermal exposure to virulent Ftt [11-16]. However, only LVS, administered by skin scarification, alleviated infections due to $F t t$ inhalation; but protection was suboptimal and could be overwhelmed by exposure to larger challenge doses [16]. Efficacy improved if LVS was administered by aerosol, but aerosol vaccination was accompanied by substantial reactogenicity [17]. Despite the drawbacks, large amounts of LVS have been produced under contract for the U.S. Department of Defense and studied as an investigational vaccine [18], but LVS remains unlicensed.

Interest in tularemia vaccines declined as the Cold War waned and bioweapon treaties were enacted. However, the 9/11 terrorist attack, followed quickly by the Amerithrax attack via the U.S. mail, rapidly rekindled interest in the development of effective countermeasures against potential biothreat agents, including Ftt [19,20]. From 2003 to 2010, U.S. spending on biodefense spurred significant activity to develop a new tularemia vaccine, and a variety of approaches have been explored as reviewed previously [21-23]. We hypothesized that a rationally attenuated vaccine based on a $F t t$ strain, such as SCHU S4, might outperform $F t h$-based LVS in terms of both safety and efficacy against $F t t$ threats [24,25]. We previously reported developing new methods to generate unmarked deletion mutants of Ftt SCHU S4 [26], first, resulting in defined mutants that lacked either FTT0918 (now called fupA) or FTT0919 (fupB) genes [24]. These were targeted because LVS, as well as another attenuated strain, Ftt FSC043, previously designated as SCHU AV [24], contained a genetic lesion spanning these two genes; this mutation was subsequently shown to be responsible for most of the attenuation of LVS [27]. However, $\triangle F T T 0919$ was not overtly attenuated for $\mathrm{BALB} / \mathrm{c}$ mice, and $\triangle F T T 0918$ was only moderately attenuated as compared with LVS and FSC043.

Therefore, we elected to generate and screen many mutant strains, with the goal of identifying another single gene deletion mutant of Ftt SCHU S4 that was at least as attenuated as LVS in mice but more effective against respiratory challenge with virulent bacteria. The screening approach is outlined in Figure 1. Briefly, each mutant's virulence was evaluated by administering $10^{3}$ colony forming units (CFU) ID, a route chosen to mimic scarification used to vaccinate humans with LVS. If mice displayed no overt disease at $10^{3} \mathrm{CFU}$ ID, additional mice were immunized ID with $10^{5}$ or $10^{7} \mathrm{CFU}$. All mice surviving vaccination were subsequently challenged ID or by aerosol with virulent Ftt FSC033 or SCHU S4.

In all, 60 gene deletion mutants, including 57 individual gene deletion mutants and three mutants spanning several genes, were generated and screened (Table 1 ). The virulence properties of most of these mutants have been previously reported by us [24,25,28-36]. Intradermal administration of several of the most highly attenuated SCHU S4 mutants, e.g., $\Delta w b t c, \Delta g p l X$, and $\Delta c l p B$, as well as FSC043 and LVS, protected BALB/c mice from a subsequent 1000 CFU ID challenge with Ftt SCHU S4 [29]. However, only Ftt SCHU S4 $\triangle c l p B$ (hereafter, $\Delta c l p B$ ), given ID, protected BALB/c mice against aerosol or IN challenge with up to $100 \mathrm{CFU}$ of SCHU S4 [37,38]. Of note, $\triangle c l p B$ was generated by deletion of 2463 out of $2580 \mathrm{bp}$ of the $\Delta c l p B$ gene, and complementation restored a wild-type level of virulence. Furthermore, deleting other genes from Columns 1-3 in Table 1 from $\Delta c l p B$ 
to yield double mutants always led to a significant decrease in protection against IN Ftt challenge of BALB/c mice [25]. Therefore, $\Delta c l p B$ was chosen for additional development. 


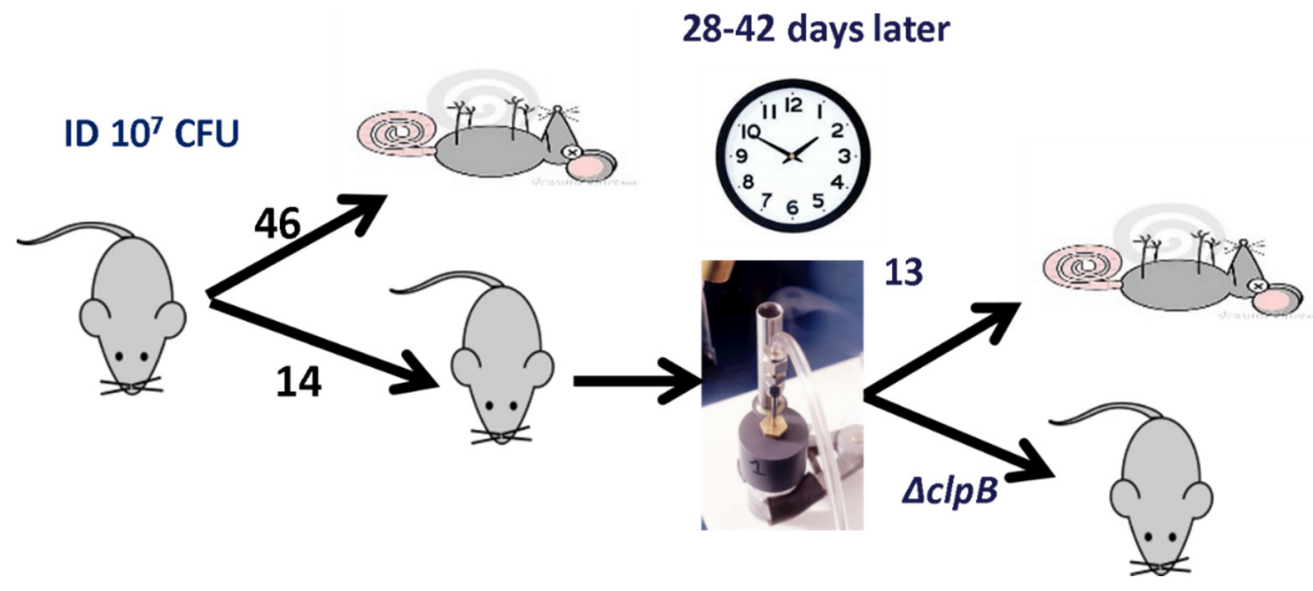

Figure 1. Mouse screening protocol for identifying SCHU S4 mutants with vaccine potential against respiratory challenge with fully virulent Ftt. For initial screening, mutants were tested for virulence at an ID inoculum of $10^{3} \mathrm{CFU}$ in young adult female BALB/c mice. Then, mutants that caused no overt signs of illness were inoculated ID at $10^{5}$ or $10^{7} \mathrm{CFU}$. Mice that survived the $10^{7}$ ID dose were then exposed to a low dose aerosol ( 100 CFU) of either Ftt strain FSC033 or SCHU S4 and were monitored for survival. $\triangle \mathrm{clp} B$ was the only mutant that was able to provide protection (survival and prolonged time to death) against aerosol challenge.

Table 1. Virulence properties of SCHU S4 deletion mutants for BALB/c mice.

\begin{tabular}{|c|c|c|}
\hline \multicolumn{3}{|c|}{ ID Virulence for BALB/c Mice of 60 Distinct Single Gene Deletion Mutants of SCHU S4 } \\
\hline ID LD $_{50}<30$ CFU $^{\mathrm{a}} \Delta F t t$ & ID LD $_{50}>10^{2}$ but $<10^{6}$ CFU $\Delta F t t:$ & ID LD $_{50} \geq 10^{7}$ CFU $\Delta F t t$ \\
\hline 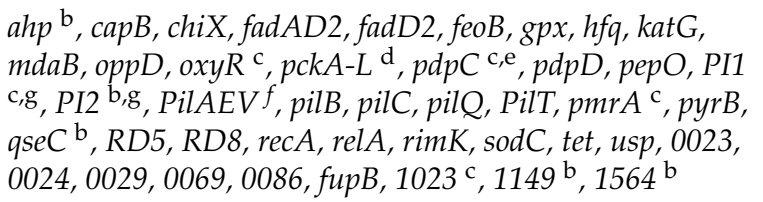 & $p c k A-S^{\mathrm{d}}, f u p A^{\mathrm{c}}, g g t^{\mathrm{f}}$ & $\begin{array}{l}\text { iglB, iglC, iglD, gplX, wbtC, wbtI, } \\
\text { clpB } \mathrm{f}^{\mathrm{f}} \mathrm{kt} A, \mathrm{lpcC}, \mathrm{purF}, \mathrm{ssp} A, \\
m g l A, \text { FLT0439 g,h FTT0085, }\end{array}$ \\
\hline
\end{tabular}

${ }^{a}$ Actual inocula ranged between 5 and $30 \mathrm{CFU} ;{ }^{b}$ extended time to death compared to SCHU S4; ${ }^{\mathrm{c}} \leq 40 \%$ survival; ${ }^{\mathrm{d}}$ pckA produced large (-L) and small (-S) colony types; ${ }^{\mathrm{e}}$ single gene copy deleted; ${ }^{\mathrm{f}} 60-100 \%$ survival against respiratory challenge ( 100 CFU IN or aerosol with SCHU S4 and/or FSC033); ${ }^{\mathrm{g}}$ deletion spanned several adjacent genes; ${ }^{\mathrm{h}}$ gene designation describing deletion found in LVS. For FTT designations see Supplementary Table S1).

Because tularemia is not only rare and sporadic in nature, but also can cause high morbidity and mortality, we expect clinical development and licensure in the USA to be pursued via the FDA "Animal Rule." This regulatory pathway allows for evaluation of efficacy using two animal models, and the approach depends on developing a rational means to bridge the outcomes from animal data to humans [39,40]. Mice are useful for virulence screening and immunological studies, while Fischer 344 rats have advantages for vaccination studies. In particular, rat infections mimic the different infection outcomes seen in humans following F. novicida or Fth infections (survival of moderate doses) as compared with $F t t$ infections (increased virulence) [41-43]. Product characterization studies of $\triangle c l p B$ described here, therefore, have taken advantage of both animal models. Efficacy and immunological correlate studies using Fischer 344 rats and cynomolgus macaques are subjects of manuscripts in preparation, while production and manufacturing-related studies are the subject of the present report.

\section{Results}

2.1. Studies Supporting Attenuation and Removal of SCHU S4 $\triangle \mathrm{clpB}$ from the U.S. Select Agent List

Mutants of fully virulent $F$. tularensis, classified as a Select Agent in the USA, continue to be considered Select Agents themselves (https:/ / www.selectagents.gov/, accessed on 25 May 2021) until evidence to the contrary is considered sufficient for any such mutants to be formally removed from the Select Agent list. In order to develop $\triangle c l p B$ as a vaccine, 
it is crucial to understand the extent of its attenuation and also to explore characteristics specifically supporting an application to remove it from Select Agent classification. Since LVS has been studied in humans and was excluded from the Select Agent list by describing evidence for its attenuation, we performed a series of experiments comparing the virulence properties of $\triangle \operatorname{clpB}$ to LVS. These experiments are summarized in Table 2. As compared to LVS, $\triangle c l p B$ infection was notably less lethal for BALB/c mice when administered intranasally (IN), produced similar or less skin necrosis and clinical signs in mice, and grew similarly in human and mouse macrophages (not shown).

Table 2. Comparisons of LVS and SCHU S4 $\Delta c l p B$ undertaken over the past 22 years (LVS) or 14 years (SCHU S4 $\Delta c l p B$ ) at the National Research Council of Canada (NRC-C) that formed part of the Select Agent removal request.

\begin{tabular}{|c|c|c|c|}
\hline Criterion & LVS & $\Delta c l p B$ & FSC033 ${ }^{a}$, SCHU S4 ${ }^{a}$ (MTD) $^{b}$ \\
\hline ID $\mathrm{LD}_{50}$ & $>10^{7} \mathrm{CFU}$ & $>10^{7} \mathrm{CFU}$ & $<10$ CFU (7) \\
\hline IN LD 50 & $\sim 10^{3} \mathrm{CFU}^{\mathrm{c}}$ & $10^{4}-10^{6} \mathrm{CFU}^{\mathrm{d}}$ & $<10$ CFU (6) \\
\hline$\%$ deaths following $\sim 10^{5}$ CFU ID ${ }^{\mathrm{e}}$ & $2.1(n=185)^{\mathrm{f}}$ & $1.4(n=560)^{\mathrm{f}}$ & 100 \\
\hline Necrosis score at site of injection & $2-3^{g}$ & $0-1^{\mathrm{g}}$ & $4^{\mathrm{g}}$ \\
\hline SCID mice MTD ID $10^{3}$ CFU ID & 15 & $17^{\mathrm{h}}$ & ND \\
\hline SCID mice MTD IN $10^{2}$ CFU IN & 14 & 19 & ND \\
\hline Clinical signs given at $10^{5} \mathrm{ID}$ & Mild & Mild & severe \\
\hline Survival SCHU S4 20-100 CFU IN ${ }^{\mathrm{i}}$ & $\leq 20 \%$ & $60-100 \%{ }^{i}$ & NA \\
\hline
\end{tabular}

${ }^{\mathrm{a}}$ Two distinct virulent strains of $F t t ;{ }^{\mathrm{b}}(\mathrm{MTD})=$ median time to death; ${ }^{\mathrm{c}} \sim 1 \times 10^{3} \mathrm{CFU}$ of LVS IN invariably killed all BALB/c mice over a 20 year span at NRC-C; ${ }^{\mathrm{d}}$ inter- experimental range; ${ }^{\mathrm{e}}$ normal ID vaccination dose; ${ }^{\mathrm{f}}$ not always head-to-head comparisons; ${ }^{\mathrm{g}}$ score range 1-6 (see Golovliov et al. [25]; ${ }^{\mathrm{h}}$ significantly longer survival as compared with LVS; ${ }^{\mathrm{i}}$ survival 42 days after immunization followed by IN challenge with 20-100 CFU of SCHU S4.

An infection of highly immunodeficient SCID mice is often used to evaluate the extent of microbial attenuation, even when the ultimate outcome of infection is death. Here, an infection of SCID mice with $\triangle c l p B$ resulted in longer times to death than those observed after LVS infection [25]. Moreover, only an infection with very large doses of $\Delta c l p B$ led to death of guinea pigs, which, like mice, are highly susceptible to virulent $F$. tularensis [9] (Figure 2).

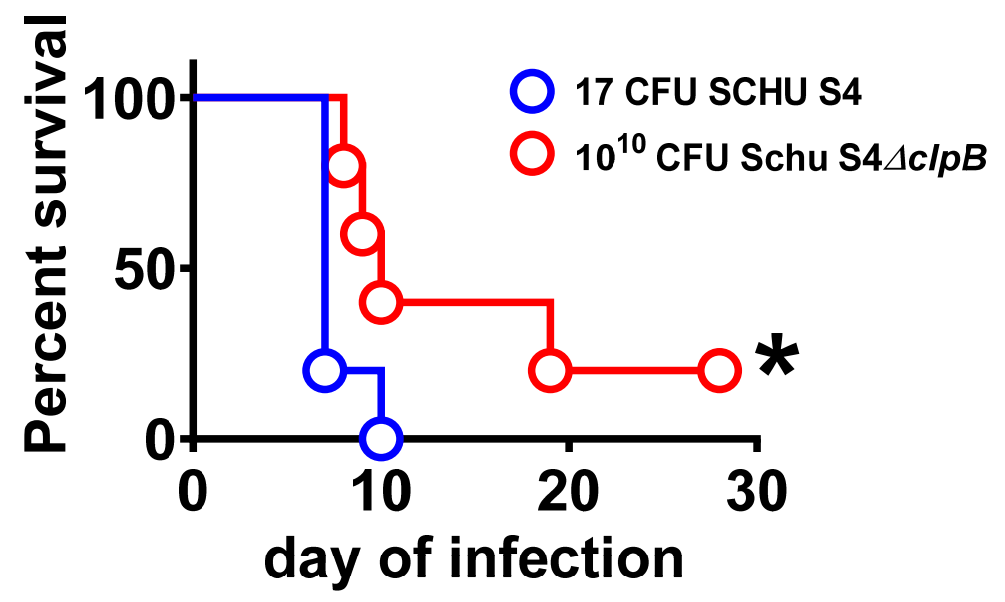

\section{*, significantly greater survival $(P<0.05)$}

Figure 2. Attenuation of $\triangle c l p B$ for guinea pigs. Guinea pigs, which are as susceptible to virulent $F t t$ challenge as mice, were administered the indicated doses of SCHU S4 or $\triangle c l p B$ SC and monitored for morbidity and mortality to further evaluate the attenuation of $\triangle c l p B$. Whilst a dose of $17 \mathrm{CFU}$ of SCHU S4 administered SC killed all guinea pigs within 10 days, $10^{10} \mathrm{CFU} \Delta c l p B$ led to significantly lower morbidity and mortality. 
Then, we evaluated the potential for $\triangle c l p B$ to revert to a virulent phenotype. For these experiments, death of BALB/c mice when given an IN dose of $10^{4} \mathrm{CFU}$ (the lowest $\mathrm{LD}_{50}$ reported for $\Delta c l p B$, Table 2) was considered to be to reflect gain of virulence. $\Delta c l p B$ was passaged in vivo through mice five times, and in vitro ten times on cysteine heart agar supplemented with hemoglobin $(\mathrm{CHAH})$ [24], and stocks prepared for infection after the last passage of each. For $\triangle c l p B$ bacteria passaged either in vivo or in vitro, all BALB/c mice survived IN inoculation at a dose of $10^{4} \mathrm{CFU}$ (Table 3, top half).

Table 3. Effect of culture conditions on attenuation of original $\triangle c l p B$.

\begin{tabular}{|c|c|c|}
\hline Source of $\Delta \mathrm{clpB}$ & $\begin{array}{c}\text { \% Survival after IN } \\
\text { Inoculation with } \sim 104 \mathrm{CFU}\end{array}$ & $\begin{array}{l}\text { \% Survival after IN Challenge with } \\
\sim 100 \text { CFU SCHU S4 } 42 \text { Days Later }\end{array}$ \\
\hline Original stock & $100 \%$ & $100 \%$ \\
\hline $10 \times$ in vitro 1 & $100 \%$ & $100 \%$ \\
\hline $5 \times$ in vivo $^{2}$ & $100 \%$ & $100 \%$ \\
\hline Original stock & $100 \%$ & $100 \%$ \\
\hline $5 \times$ in $\mathrm{CDM}^{3,4}$ & $60 \%$ & $100 \%$ \\
\hline Fermenter $\mathrm{CDM}^{5}$ & $40 \%$ & $100 \%$ \\
\hline
\end{tabular}

${ }^{1}$ Original stock passaged by serial streaking for confluent growth on $\mathrm{CHAH}$ followed by $48 \mathrm{~h}$ incubation at $37^{\circ} \mathrm{C}$ final passage was resuspended in freezing medium and used herein [24]; ${ }^{2}$ serial passage of infected spleens by IP inoculation without intervening in vitro passage, spleen from the 5 th passage was grown to confluence on $\mathrm{CHAH}$ agar, resuspended in freezing medium, and used herein; ${ }^{3} \mathrm{CDM}$, Chamberlains defined broth [44]; ${ }^{4}$ passaged $5 \times$ in CDM for acclimation prior to ${ }^{5}$ fermenter growth.

To evaluate the potential for recombination, we further evaluated stocks of bacteria in which $\triangle c l p B$ was co-cultured on $\mathrm{CHAH}$ agar with a distinct SCHU S4 $\triangle$ iglC deletion mutant through 5 passages in vitro. All of the mice survived infection with $10^{8}$ co-cultured bacteria (Figure 3); furthermore, these mice were effectively vaccinated, since all survived when subsequently challenged with fully virulent SCHU S4. Other mice received the same amount of co-cultured bacteria spiked with 50 CFU SCHU S4; about 35\% of these mice survived. Normally, ID inoculation of 50 CFU of SCHU S4 alone would result in 100\% deaths (mean time to death of 7 days). However, mixing with co-cultured bacteria seems to have somewhat blunted the virulence of the fully virulent bacteria, possibly because the massive excess of the co-cultured bacteria induced concomitant inflammatory immune responses. The combined data above led to the removal of $\Delta c l p B$ from the Select Agent list in 2014 (https: / / www.selectagents.gov / sat/exclusions/hhs.htm, accessed on 27 May 2021). Subsequently, exclusion was applied to $\Delta c l p B$ carrying any additional mutations ( $\mathrm{T}$. $\mathrm{Wu}$, personal communication).

\subsection{Clearance of $\Delta c l p B$ from Fischer Rat Tissues}

As noted, Fischer 344 rats provide a valuable model for testing tularemia vaccines [42,43,45-47]. Therefore, we expect rats to be used for testing tularemia vaccines under the "Animal Rule". Thus, we evaluated distribution and clearance of $\Delta c l p B$ from the spleens of infected male and female rats given ID doses of $\Delta c l p B$ ranging from $10^{3}-10^{9} \mathrm{CFU}$. All rats survived infection, and no bacteria were detected in spleens by 40 days after infection (Figure 4). No significant differences in bacterial burdens were found between male and female rats at any dose on any day. While rats survived ID infection with $10^{9} \mathrm{CFU}, 10^{10} \mathrm{CFU}$ ID was uniformly lethal for both sexes (data not shown).

In a separate experiment, male and female rats were inoculated ID with 30,300 , or $3000 \mathrm{CFU}$ of $\Delta c l p B$, and splenic burdens were determined on Day 14. One spleen from a female rat inoculated with $30 \mathrm{CFU}$ was sterile. All other rats had a splenic burden of $\sim 4.5 \log _{10}$, with no significant differences among groups (data not shown). Taken together, these data support performing challenge studies of vaccinated rats after Day 30, when vaccinating bacteria are no longer present in tissues. 


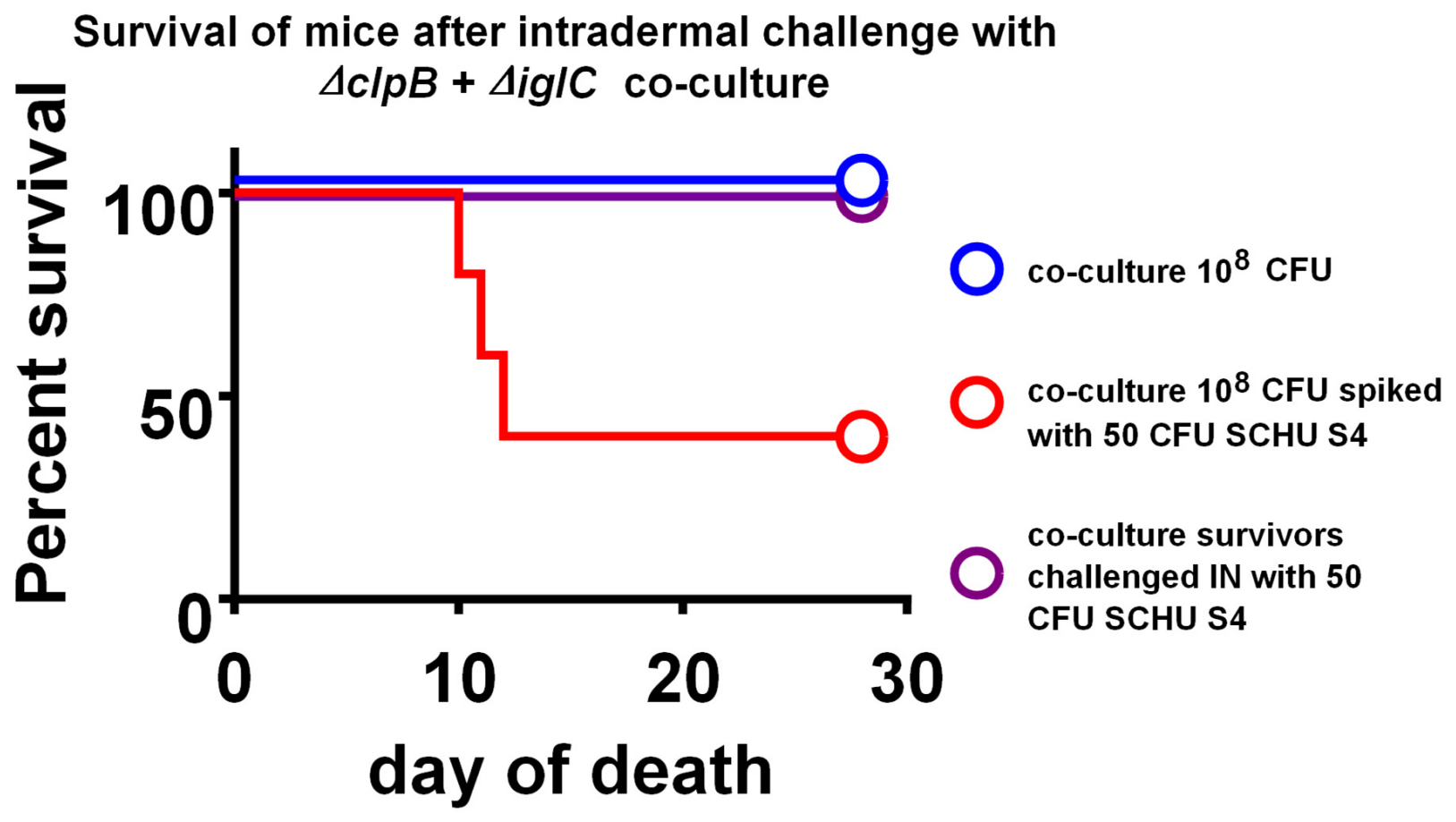

Figure 3. Failure of $\triangle c l p B$ to revert to a virulent phenotype following prolonged co-culture with another highly attenuated SCHU S4 $\triangle i g l C$ mutant. The mutants were both co-cultured on $\mathrm{CHAH}$ agar for $48 \mathrm{~h}$ through five passages, as described in Materials and Methods. Thereafter, proteomics (2D PAGE followed by mass spectrometry) confirmed the presence of the $\mathrm{clpB}$ and iglC proteins at levels expected from either mutant alone. BALB/c mice were administered the indicated CFU of co-cultured bacteria ID and monitored for survival. Co-cultured bacteria remained as attenuated for BALB/c mice as the individual mutants, whereas spiking the co-culture preparation with as few at 50 CFU of wild-type SCHU S4 was sufficient to cause death. Co-cultured bacteria also engendered protection; following administration of co-cultured bacteria, surviving mice were also challenged with 50 CFU SCHU S4, and all survived.
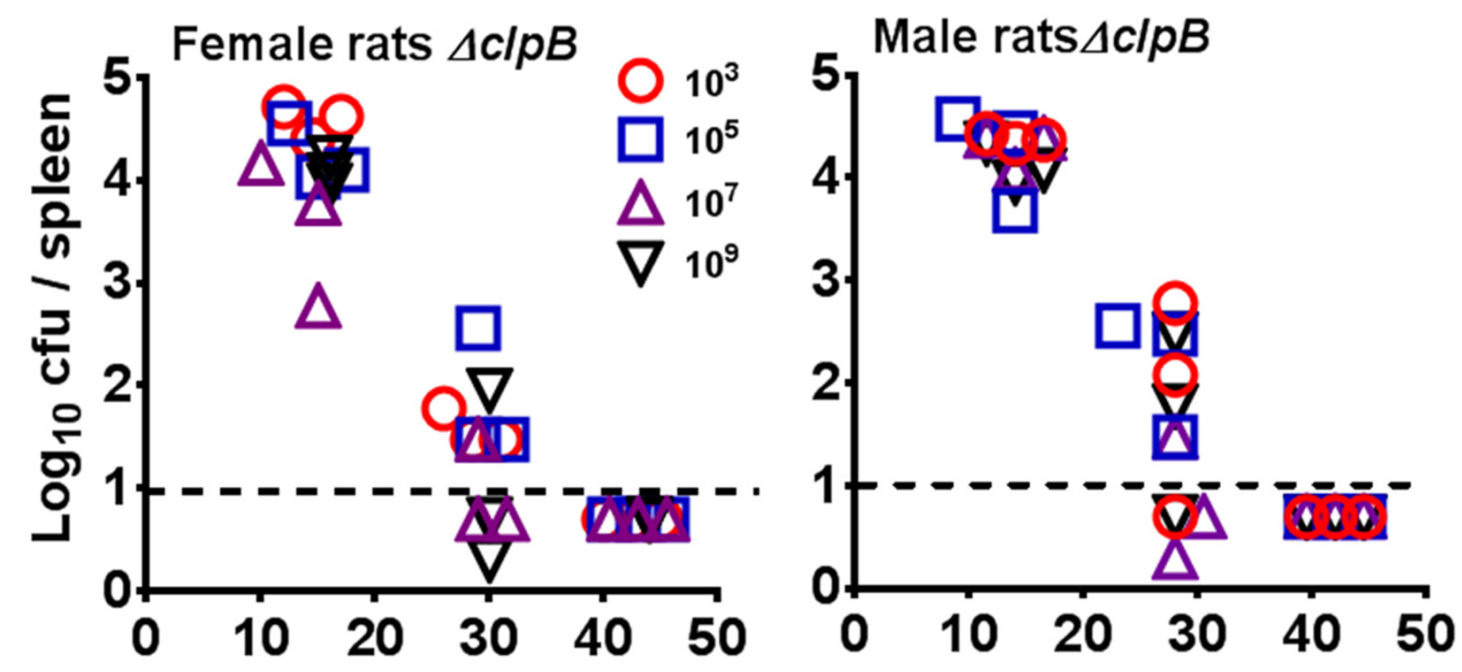

\section{Days after vaccination}

Figure 4. Clearance of $\triangle c l p B$ from the spleens of vaccinated Fisher 344 rats. Young adult male and female Fischer rats were inoculated ID with the indicated doses of $\Delta c l p B$. At the indicated times after inoculation, rats ( $n=3 /$ group) were euthanized and the splenic burdens of $\Delta c l p B$ determined. As illustrated, rats of either sex cleared $\Delta c l p B$ between 30 and 42 days after vaccination. Dashed horizontal line shows limit of detection. 


\section{3. $\triangle$ clpB Vaccine Production Optimization, Scale-Up, and Quality Control Testing}

The original clinical lots of LVS, made in the 1960s, and the LVS lots made in the 2000s by the DynPort Vaccine Company (DVC), were both produced by growing LVS in modified casein partial hydrolysate $(\mathrm{MCPH})$ broth $[9,18]$. At NRC-C, an initial stock of $\triangle c l p B$ was made from a slant growth of the mutant obtained from Umea University. This was expanded by confluent growth on $\mathrm{CHAH}$, and then subsequently harvested and resuspended in freezing medium [24], dispensed into $1.0 \mathrm{ml}$ aliquots, and stored at $-80^{\circ} \mathrm{C}$. This is referred to as "original stock" throughout the current manuscript. Then, a working research cell bank was prepared at NRC-C by passaging original $\triangle c l p B$ five times in $\mathrm{MCPH}$ broth, and the final passage was used to prepare $1000 \times 1.0 \mathrm{~mL}$ vials that were stored at $-80{ }^{\circ} \mathrm{C}$. This is referred to as "new stock" throughout the current manuscript and served as a research cell bank. Vials of new stock were shared among the vaccine development teams (see authorship for affiliations) and were used as the starting material for all subsequent vaccine development studies reported herein and elsewhere. The characteristics of new stock $\Delta c l p B$ are listed in Table 4 as compared with "original stock" (i.e., before passage through $\mathrm{MCPH}$ broth); all were considered to be representative of results to date and acceptable as bacterial source stocks for future work. Subsequently, a cGMP master cell bank was prepared at a commercial manufacturing organization, Ology Bioservices, from a single isolated colony, frozen in freezing medium in $1 \mathrm{~mL}$ vials, and characterized, as described in Supplementary Table S2.

Table 4. Characterization of $\Delta c l p B$ used to produce a research cell bank.

\section{Characteristic}

Time of harvest from flask

$\mathrm{CFU} / \mathrm{ml}$ at harvest ${ }^{\mathrm{a}}$

Cryopreservative

Colony morphology $b$

Gram stain ${ }^{\mathrm{C}}$

Lytic phage

Lysogenic phage

Contaminant bacteria $\mathrm{d}$

Genomic sequence ${ }^{\mathrm{e}}$

42-day survival of mice after $10^{4} \mathrm{CFU}$ IN administration (original stock/new stock) ${ }^{\mathrm{f}}$

42-day survival of mice following $10^{5}$ CFU ID administration

(original stock/new stock)

Clinical signs $\mathrm{g}$ (original vs. new stock)

Skin reactogenicity $\mathrm{g}$ (original vs new stock)

$\triangle c l p B$ organ load (skin, spleen, liver, lung) 4 days after ID

vaccination with $10^{5} \mathrm{CFU}$ of original vs. new stock.

Day 4 serum cytokine/chemokine levels (21-plex assay)

(original vs. new stock)

28-day survival against IN challenge with 100 CFU SCHU S4

after IN vaccination (original/new stock)

Protection against IN challenge with $~ 100$ CFU SCHU S4 after

ID vaccination original/new stock (MTD in days)

Protection against ID challenge with $10^{5}$ CFU SCHU S4 or

FSC033 after ID vaccination
$20.75 \mathrm{~h}$

$3.9 \times 10^{9}$

Sucrose $10 \%$ w/v

Typical of Ftt and Fth

Typical of Ftt and Fth

Negative

Negative

Negative

Identical to original mutant

$100 \% / 60 \%$ at day $42 ; \mathrm{NS}^{\mathrm{h}}$

$100 \% / 100 \%$

Significantly greater vs. old stock on days 3,4 , and 5 NS h

$\Delta c l p B$ lung burden was significantly higher $(p=0.016)$ for new vs. original stock

NS ${ }^{h}$

$100 \% / 100 \%$

$60 \%(28) / 0 \%(16) . \mathrm{NS}^{\mathrm{h}, \mathrm{i}}$

$100 \% / 100 \%$

${ }^{a}$ Average from plating of 2 vials each by three individuals; ${ }^{\mathrm{b}}$ after $48 \mathrm{~h}$ growth on Oxoid chocolate II agar; ${ }^{\mathrm{c}}$ no evidence of contaminating bacteria; ${ }^{d}$ several vials were plated on regular Oxoid chocolate agar or sheep blood agar, and incubated aerobically, microaerophilically, or anaerobically at $37{ }^{\circ} \mathrm{C}$ for $72 \mathrm{~h}$; ${ }^{\mathrm{e}}$ no evidence of any contaminating DNA; ${ }^{\mathrm{f}}$ inocula for old vs. new stock were $7 \times 10^{3} \mathrm{CFU}$ vs. $1.32 \times 10^{4} \mathrm{CFU}$; $\mathrm{g}$ scored blind by NRC-C animal resources staff; ${ }^{\mathrm{h}}$, not significantly different from each other; ${ }^{\mathrm{i}}$ when compared to naïve mice (MTD 5 days) and corrected for multiple comparisons.

A major hurdle in vaccine development is the ability to scale-up production to levels suitable for the target population. Previously, LVS growth for extraction of $F$. tularensis LPS in a 30-liter BSL3 fermenter (working volume 22 L) at NRC-C [48] resulted in yields of 
$10^{14} \mathrm{CFU}$, an amount sufficient for $\sim 10$ million ID human doses or 1 million scarification doses, assuming a dose similar to LVS [49], the difference reflecting the wastage inherent to the latter administration route. Therefore, we evaluated growth approaches amenable to a $22 \mathrm{~L}$ scale and which were appropriate for GMP production. First, we explored growth in Chamberlain's defined broth (CDB), since all ingredients are available in a highly purified form and not sourced from cows (minimizing the risk of contamination by bovine spongiform encephalopathy prions). Because previous reports [50] indicated that LVS grown in CDB increased in virulence for mice, we tested the virulence of $\Delta c l p B$ grown to $22 \mathrm{~L}$ scale in $\mathrm{CDB}$. The results showed that fewer mice infected IN with $\Delta c l p B$ either passaged in CDB or grown at scale in CBD survived infection with $10^{4} \mathrm{CFU}$ as compared with the starting stocks grown at lab scale (Table 3, bottom half). Although the significance of the subtle change in $\triangle c l p B$ when grown in CDB is not clear, we elected to evaluate growth of $\triangle c l p B$ in $\mathrm{MCPH}$, the medium used to develop the original human lots of LVS and later used by DVC. We produced three $22 \mathrm{~L}$ fermenter batches at NRC-C at 1-2-year intervals, the latter two using $\triangle c l p B$ research cell bank stocks. The outcomes of fermentation at scale appeared to be highly reproducible in terms of yield from the starter culture flasks, yields from fermenter growth, bacterial doubling time, and biomass (Table 5). The $\triangle c l p B$ growth curve from the second NRC-C fermenter run (Table 5) as monitored by $\mathrm{OD}_{600}$, illustrates growth in $\mathrm{MCPH}$. During fermenter runs two (Figure $5 \mathrm{~A}$ ) and three (not shown), $\Delta c l p B$ cultures were sampled at various intervals which represented late log phase, early stationary phase, and mid-stationary phase. On the basis of the results from testing these samples in putative lot release and biological characterization assays (see below), we considered the early mid-stationary phase to be the optimal time period for harvest. Approximately $200 \mathrm{~mL} /$ time point of fermenter growth was sufficient for R\&D purposes at NRC-C. Fermenter contents collected at the end of NRC-C fermenter Run 1 (Table 5) were used for long-term preservation studies. To mimic large-scale diafiltration prior to lyophilization, $\sim 100 \mathrm{~mL}$ was centrifuged at $6700 \times \mathrm{g}$ for $20 \mathrm{~min}$ at $+4{ }^{\circ} \mathrm{C}$. The pellet was washed once in lyophilization medium and resuspended in $50 \mathrm{~mL}$ of the same, and then aliquoted into $5 \mathrm{~mL}$ lyovials in $2 \mathrm{~mL}$ volumes (concentrated stock). Additionally, a 1/1000 dilution of the concentrated stock was made in lyophilization medium and dispensed as above for freeze-drying. The LVS vaccine produced in the 1960s contained 50 doses/vial, whilst that produced by DVC contained a single $\left(2 \times 10^{7} \mathrm{CFU}\right)$ dose. Therefore, we attempted to mimic both of these situations with $\triangle c l p B$. For all other purposes, sucrose was added to $10 \% w / v$ to the $\mathrm{MCPH}$ growth, aliquoted in $1.0 \mathrm{~mL}$ volumes, and frozen at $-80{ }^{\circ} \mathrm{C}$ until required. The bulk of the fermenter growth was harvested by centrifugation, and the cell paste stored in 50-200 $\mathrm{g}$ amounts and frozen at $-80^{\circ} \mathrm{C}$.

SOPs developed during fermenter Run 2 were transferred to Ology Biosciences. Several process development runs were performed to demonstrate the reproducibility of the procedure developed at NRC-C. As shown in Figure 5B,C, the growth patterns of $\Delta c l p B$ in two difference process runs were nearly identical, and very similar to Run 2 at NRC-C (Figure 5A). Then, a $25 \mathrm{~L}$ scale manufacturing run was performed. The product from the initial $25 \mathrm{~L}$ run was characterized, and the bulk product conformed to expected characteristics (Supplementary Table S3). The products generated from these runs were then diluted in lyophilization buffer to a target concentration of $5 \times 10^{8} \mathrm{CFU} / \mathrm{mL}$ and subsequently lyophilized (see below). The final drug product was then characterized using a panel of working lot release assays, as described in Table 6. 
Table 5. Comparison of $\triangle c l p B$ yields from $22 \mathrm{~L}$ fermenter runs at NRC-C in MCPH broth.

\begin{tabular}{|c|c|c|c|c|c|c|c|c|}
\hline Date of Run & $\begin{array}{c}\text { Flask Starting } \\
\text { Inoculum CFU/mL }\end{array}$ & $\begin{array}{c}\text { Flask Harvest } \\
\text { Concentration CFU/mL } \\
\text { (Culture Time, h) }\end{array}$ & $\begin{array}{c}\text { \#Doublings } \\
\text { (Doubling Time, h) }\end{array}$ & $\begin{array}{c}\text { Fermenter } \\
\text { Inoculum CFU/mL }\end{array}$ & $\begin{array}{c}\text { Fermenter Harvest } \\
\text { Time, h } \\
\text { (CFU/mL) }\end{array}$ & $\begin{array}{c}\text { \#Doublings } \\
\text { (Doubling Time, h) }\end{array}$ & $\begin{array}{l}\text { Total CFU } \times 10^{14} \\
\left(\# \text { Doses } \times 10^{6}\right)^{1}\end{array}$ & Biomass $\mathrm{g}$ \\
\hline December 2014 & $4.0 \times 10^{7}$ & $5.2 \times 10^{9}(18.5)$ & $7(2.6)$ & $3.90 \times 10^{6}$ & $22\left(1.1 \times 10^{10}\right)$ & $12(1.85)$ & $242(24)$ & 177.3 \\
\hline September 2015 & $2.6 \times 10^{7}$ & $9.0 \times 10^{9}(18.25)$ & $8.4(2.1)$ & $1.40 \times 10^{7}$ & $20.5\left(1.1 \times 10^{10}\right)$ & $10(2.3)$ & $242(24)$ & 204.1 \\
\hline June 2017 & $7.8 \times 10^{6}$ & $9.0 \times 10^{9}(18.5)$ & $10.2(1.8)$ & $1.43 \times 10^{7}$ & $26\left(1.1 \times 10^{10}\right)$ & $10(2.9)$ & $242(24)$ & $74.9^{2}$ \\
\hline
\end{tabular}

${ }^{1}$ \# of human doses based on an inoculum size of $10^{7} \mathrm{CFU} / \mathrm{ml}$ as used for $\mathrm{LVS} ;{ }^{2}$ remaining biomass after periodic sampling. 

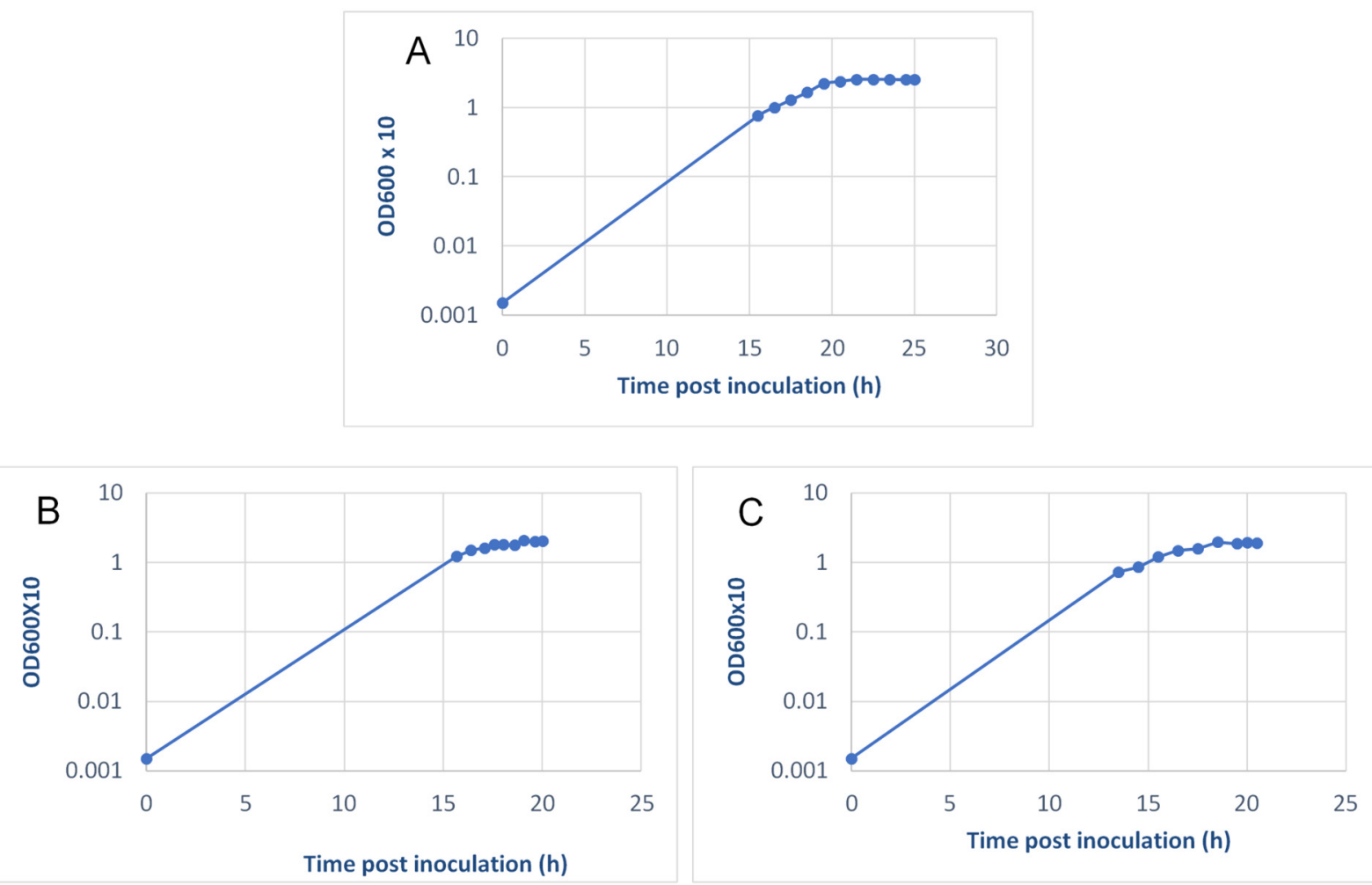

Figure 5. Reproducibility of the $25 \mathrm{~L}$ manufacturing process. $\triangle c l p B$ was cultured as described in Materials and Methods. Aliquots were sampled from approximately $15 \mathrm{~h}$ onwards and growth was monitored by $\mathrm{OD}_{600}$; samples were diluted 1:10 prior to reading. The line from 0 to $15 \mathrm{~h}$ is stylized from the fermenter printouts to avoid potential contamination of the fermenter vessels by sampling at low $\Delta c l p B$ levels. (A) NRC-C Run 2); (B) ology process Run 1; (C) ology process Run 2.

Table 6. Quality control testing of the final drug product.

\begin{tabular}{|c|c|c|}
\hline Parameter & Test Method & Specification \\
\hline & $c l p B$ specific PCR & Identity confirmed ${ }^{\mathrm{a}}$ \\
\hline & Purity & Absence of contaminating organisms ${ }^{b}$ \\
\hline & $\mathrm{CFU} / \mathrm{mL}$ & Report result \\
\hline & Gram Stain & Gram negative coccobacillus \\
\hline & $\mathrm{TBD}^{\mathrm{c}}$ & Round, smooth and slightly mucoid single colonies \\
\hline & $\mathrm{CFU} / \mathrm{Ml}^{\mathrm{d}}$ & Report result \\
\hline & LAL $^{\mathrm{e}}$ & $<5 \mathrm{EU} / \mathrm{kg} /$ dose \\
\hline & $\begin{array}{l}\text { Susceptible to tetracycline, levofloxacin, } \\
\text { gentamycin, chloramphenicol, ciprofloxacin, } \\
\text { streptomycin, rifampin }{ }^{\text {f }}\end{array}$ & Susceptible \\
\hline & Karl Fisher $g^{1}$ & Report Result \\
\hline & Appearance of cake ${ }^{\mathrm{h}}$ & Report result \\
\hline
\end{tabular}

${ }^{\text {a }}$ Whole genome sequencing was performed on Master Cell Banks, the PCR method developed to demonstrate the absence of intact $c l p B$ gene is described in methods section; ${ }^{\mathrm{b}}$ growth on multiple media known to support and inhibit the growth of $\Delta c \operatorname{lp} B ;{ }^{\mathrm{c}}$ bacteria were grown on chocolate agar plates; ${ }^{\mathrm{d}}$ Bacteria were counted prior to placing into a known volume of media, samples were taken at various times, plated on agar plates, and colonies counted; ${ }^{\mathrm{e}} \mathrm{LAL}=$ limulus amoebocyte lysate assay using an Endosafe nexgen-PTS system (depending on the safety margin required by the regulator, the required test dose of $\triangle c l p B$ could fail this test because it possesses intact LPS albeit with low endotoxicity [51], ${ }^{\mathrm{f}}$ by antibiotic disc assay on chocolate agar medium; ${ }^{\mathrm{g}}$ for dryness of lyophilized cake; ${ }^{\mathrm{h}}$ color and form as compared with a standard sample, ease of solubilization, residual solids after reconstitution. 


\subsection{Long-Term Storage of $\Delta c l p B$}

The LVS produced in the 1960 s was lyophilized and frozen at $-80^{\circ} \mathrm{C}$ at a concentration of $5 \times 10^{10} \mathrm{CFU}$; the original lyophilized vials have been used for in vitro, preclinical, and clinical studies up to the present [9,52-54]. This experience with successful long-term storage of LVS was the basis for testing similar storage conditions for $\Delta c l p B$. The original vaccine lots and the newer lots produced by DVC both used $10 \mathrm{mM}$ phosphate buffer containing $10 \% w / v$ sucrose and $1.3 \%$ gelatin as the lyophilization medium $[9,18]$. In the former case, a 90\% loss in viability, measured as a decline in CFU, was associated with lyophilization and reconstitution in water for injection, whereas DVC did not report similar data in published work. Others empirically tested multiple other matrices for foam-drying of LVS [55], the best of which showed no loss of viability after twelve weeks of storage at $25^{\circ} \mathrm{C}$. The lyophilization process described by Eigelsbach and Downs [9] and Pasetti et al. [18], when applied to $\Delta c l p B$, resulted a in viability loss of $>99 \%$ (not shown). Furthermore, we did not have access to the foam drying apparatus used by Ohtake et al. [55]. Therefore, we empirically tested lyophilization formulations comprised of various concentrations of mannitol, sucrose, trehalose, and gelatin in $10 \mathrm{mM}$ phosphate buffer. Ultimately, we found that lyophilization in $10 \mathrm{mM}$ phosphate buffer, containing $1 \% w / v$ sucrose, $1 \% w / v$ mannitol, and $0.25 \% w / v$ gelatin, resulted in an approximately $50 \%$ decrease in viability immediately following lyophilization and reconstitution which was considered to be an acceptable outcome (Figure 6). Recovery was similar when $\triangle c l p B$ prepared using this formulation was stored at -20 or $-80^{\circ} \mathrm{C}$ for more than 3 years (Figure 6). In contrast, storage at $+4{ }^{\circ} \mathrm{C}$, for the same period of time, resulted in an additional 50\% decrease in viability. In contrast, no viable bacteria were recovered after storage at an ambient temperature for $<6$ months (not shown). Viability was similar whether $\Delta c l p B$ was lyophilized neat $\left(10^{10} \mathrm{CFU} /\right.$ vial) or a 1:1000 dilution (107 CFU/vial), as shown in Figure 6.

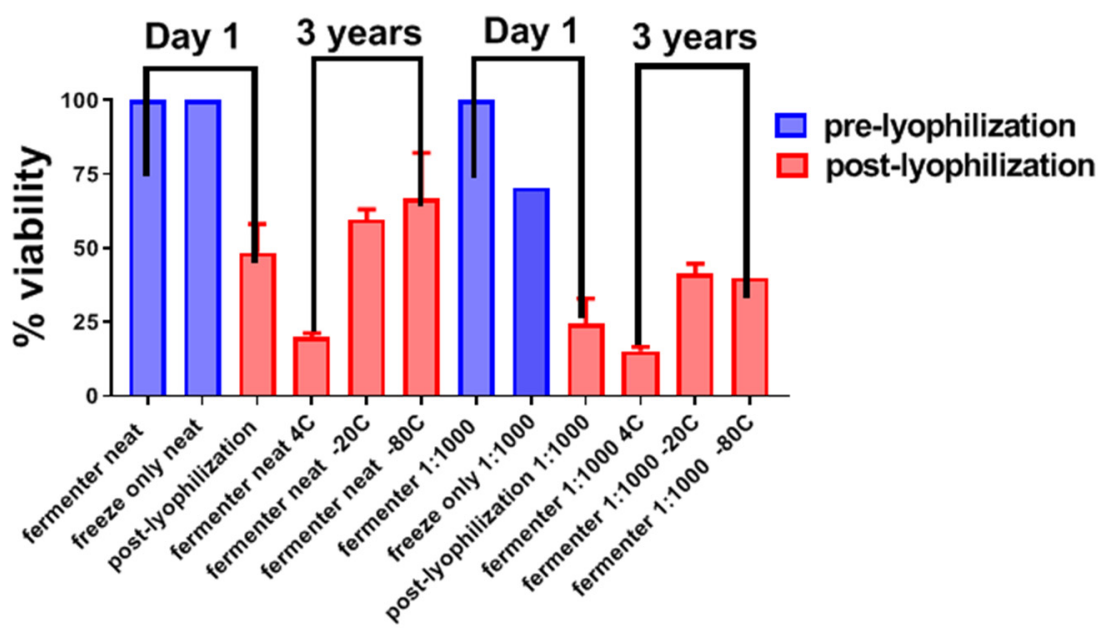

Figure 6. Viability of $\triangle \operatorname{clp} B$ following lyophilization and prolonged storage at different temperatures. $\triangle c l p B$ was obtained from a fermenter run, and the suspension buffer was exchanged with lyophilization matrix by centrifugation and washing twice with matrix. At high concentration $\left(\sim 10^{10} \mathrm{CFU} / \mathrm{mL}\right)$, freezing the samples prior to lyophilization had no impact of the viability of $\Delta c l p B$, but at a lower concentration $\left(\sim 10^{7} \mathrm{CFU} / \mathrm{mL}\right.$ ), this was reduced by $\sim 25 \%$ (not shown). On Day 1 following lyophilization, the viability of $\Delta c l p B$ decreased $\sim 50 \%$ and $\sim 75 \%$ at the higher and lower concentration, respectively. Next, lyophilized $\triangle \operatorname{clp} B$ was stored for 3 years at +4 or $-20^{\circ} \mathrm{C}$ or $-80^{\circ} \mathrm{C}$. Lyophilized $\triangle c l p B$ stored at $+4{ }^{\circ} \mathrm{C}$ only decreased further in viability to $\sim 50 \%$ at this time point.

\subsection{Quality Control and Lot Release Assays for Clinical Lots of $\Delta c l p B$}

Establishment of a panel of robust in-process quality control (QC) assays and lot release assays, including those used for stability testing, are an essential component of product development. We expected to include traditional QC testing applied to control 
consistent production of live attenuated vaccines (e.g., monitoring bacterial growth, sterility, $\mathrm{pH}$, osmolarity, moisture retained in final lyophilized vials, endotoxin, and tests for excipients and residual materials of concern, as detailed in Table 6 and Supplementary Tables S2 and S3. Additionally, in the current studies, samples of $\Delta c l p B$ collected at various stages of the development process (Supplementary Tables S4 and S5) were subjected to a battery of biological tests to determine whether these showed any deviations that might correlate with a loss of potency. In total, eight different experiments performed over a period of 10 years yielded comparable results with all parameters tested. Among other assessments, serum cytokine and chemokine levels four days after ID vaccination with the various $\Delta c l p B$ samples were comparable, including when measured using different Luminex technologies (fluorescent versus magnetic beads) and instruments (Luminex Magpix vs LS100). This outcome suggests the robustness of this assay.

\section{Discussion}

The development of vaccines against tularemia was originally prompted by the need to control endemic disease. In the early half of the 20th century, Fth was responsible for large epidemics involving millions of cases in the former USSR [10]. In North America, tularemia caused by both Fth and Ftt was recognized as an occupational and recreational hazard [15,56-58]. Historically, inhalation of $F t t$ had a mortality rate of $>30 \%$ before the antibiotic era [1], and human infection studies have demonstrated that inhalation of as few as $20 \mathrm{CFU}$ of Ftt caused severe infection that required intervention with streptomycin [12]. The incidence of tularemia worldwide declined dramatically during the latter part of the 20th century, likely related to changes in housing and work patterns, and antibiotic development made tularemia a treatable disease when promptly diagnosed. More recently, tularemia vaccines have been of interest due to the biodefense considerations. Nonetheless, some areas of the former Soviet Union continue to use live attenuated vaccines to respond to tularemia outbreaks [59], and vaccination may be of interest here and in areas such as central Sweden and Turkey $[60,61]$, which suffer episodic disease. Therefore, vaccines such as $\triangle c l p B$ may be useful as a biowarfare deterrent and response, and for public health purposes.

Standards and expectations for biological product development, including new vaccines, have changed dramatically since LVS was derived and human studies initiated in the 1960s. Currently, most new vaccines are subunit formulations, comprised of pathogen components and adjuvants. These approaches are most applicable to viral and bacterial pathogens for which induction of specific antibodies and memory $\mathrm{B}$ and $\mathrm{T}$ follicular helper (Tfh) cells dominate protective mechanisms, as reviewed in [62]. In contrast, relatively few vaccines have been developed against intracellular bacteria such as Francisella. For a variety of reasons, some of which remain poorly understood, live attenuated vaccines have held the most promise for providing substantial and durable protection against this class of microbes [63]. For example, Fth-derived Strain 15 was used in mass vaccination campaigns in the USSR that ameliorated large natural tularemia outbreaks $[10,64]$. However, because growth conditions may alter bacterial properties and because terminal sterilization is not possible for a live bacterial product, production of live attenuated vaccines presents unique challenges. Moreover, by definition, live attenuated strains pose inherently more risk for human use than static vaccines, inviting scrutiny that necessitates additional product characterization.

The difficulties in advancing vaccine candidates to market is perhaps illustrated by the experience with LVS, which remains unlicensed despite decades of study. Strain 15 , one of the predecessors of LVS, and LVS itself, have been developed empirically by repeated passages in vitro and in vivo $[9,65]$. A lack of understanding about the genetic basis for attenuation has been accompanied by concerns about reversion of LVS to wildtype Francisella, and underlying genetics were not understood until the development of sequencing methods that allowed complete evaluation of the entire bacterial chromosome. This concern has largely been alleviated by subsequent genetic studies [27], and DVC's 
efforts supported by NIH have produced new lots of LVS for human use by better controlled manufacturing procedures $[18,66]$. Nonetheless, to the best of our knowledge, no party is currently interested in advancing LVS toward licensure.

Other new tularemia vaccine candidates include the use of killed or subunit protein vaccines with various adjuvants, heterologous attenuated recombinant vaccines, and attenuated mutants of LVS, F. novicida, Ftt, and Fth. The properties and relative merits of these have been reviewed elsewhere [67]. We propose that $\Delta c l p B$ provides a genetically stable, well-defined alternative to LVS. The focus on $\triangle c l p B$ was based in part on the observation that a natural mutant of SCHU S4, Ftt strain FSC043, which contains a similar genetic lesion as LVS, was at least as attenuated for mice as LVS but protected mice better against aerosol challenge with Ftt strain FSC033 [24]; notably, FSC033 is a clinical isolate that is more virulent than SCHU S4 in rodents [68]. This may be because Ftt expresses several immunogenic antigens that are lacking in Fth strains, some of which could provide additional protection against the most virulent $F t t$ strains as compared with LVS. This hypothesis has also been borne out by data involving various mutants of $F t t$ and $F t h$ lacking the $\triangle c l p B$ gene [25]. Most recently, extensive efficacy studies using rats and cynomolgus macaques have demonstrated that $\triangle c l p B$ provided excellent and durable protection against aerosol challenge with Ftt SCHU S4 (manuscripts in preparation).

An emphasis has been placed on developing live vaccines, which contain two attenuating mutations, to decrease risk of reversion. However, data following initial screening indicated that $\triangle c l p B$ was an excellent candidate in terms of both safety and efficacy (Tables 1, 3 and 4, and Figure $3[25,29,38,69]$ ), but further deletions impaired its efficacy potential [25]. Instead of seeking double mutants, therefore, we focused on extensive safety-related characterizations of $\Delta c l p B$, as detailed here. In vitro passage studies, including co-culture studies to mimic the worst-case scenario of recombination with virulent Francisella in nature (Table 3, Figure 3), support the conclusion that the risk of revision of this large deletion is below any limit of detection. Studies in vivo using mice, guinea pigs, and rats (Table 2, Figures 2 and 4) further support a very high level of $\Delta c l p B$ attenuation. We considered clearance studies using rats to be particularly important. Although evaluation of some tissues was limited by microbiota-related overgrowth, rat spleens were uniformly free of contaminants. In mice, the spleen is the last of the organs to clear LVS, $\Delta c l p B$, and other mutant $F$. tularensis strains $[29,37,70]$. If the same holds true for rats, then, splenic clearance is the most important tissue to monitor.

A package including all safety-related data described was submitted to the CDC for review, and the request to exclude $\Delta \operatorname{clp} B$ from the Select Agent list was granted in November 2014. The same data package was sent to the Public Health Agency of Canada (PHAC), and $\triangle c l p B$ was reclassified to containment level 2 (CL2/BSL2) for in vivo and in vitro uses, including large-scale production. Additionally, based on the relative virulence for mice of $\Delta c l p B$, the PHAC also reclassified SCHU S4 $\Delta w b t C, \Delta w b t I, \Delta k d t A, g l p X$, and $\triangle l p c C$ mutants as CL2 pathogens (https:/ / health.canada.ca/en/epathogen, accessed on 27 May 2021). Since the approvals from CDC and PHAC, we further evaluated the stability of the $\triangle \operatorname{clp} B$ genome at various stages of the development process described herein. We found that no genomic changes occurred as a result of the various manipulations used in the manufacture of this mutant strain; demonstrated the lack of detectable contamination of $\Delta c l p B$ research lots by exogenous bacteria; and demonstrated the lack of detectable lytic or lysogenic phages from $\triangle c l p B$ stocks used in all stages followed for the GMP production of $\triangle c l p B$ (data not shown). Collectively, the available data support the substantial degree of irreversible attenuation of $\Delta c l p B$.

Production studies described here (Tables 4-6, Figure 5) clearly demonstrate successful scale-up. Of note, most studies described here were performed with $\triangle c l p B$ produced at a 20-22 L scale, sufficient for millions of doses. Equally important, experience with LVS and now with $\triangle c l p B$ indicate that lyophilization conditions have been defined that allow for long-term storage (Figure 6). This is an important feature for inclusion in stockpiles held for biodefense purposes. Given the excellent preservation of viability of $\Delta c l p B$ in the 
medium developed here for a minimum of 3 years and given the prolonged preservation of lyophilized LVS following an initial $90 \%$ decline in viability, we anticipate successful storage of the former at $+4,-20$, or $-80{ }^{\circ} \mathrm{C}$ could lead to multi-decade preservation similar to that observed with LVS.

Working quality control tests to evaluate newly produced lots as well as stability have been established and continue to be refined. Our research and product development experience, to date, further suggests several additional approaches for $\Delta c l p B$-specific identity, safety, and potency tests. For example, identity testing by qRT-PCR based on deletion of the $\triangle c l p B$ gene and the expected sequences of the surrounding bacterial chromosomal changes has been established and qualified by Ology Biosciences. Understanding of the residual virulence and behavior during infections of mice and rats (Tables 1-4) suggests options for initial safety testing that may ultimately be replaced by in vitro measures, including sequence data.

Arguably, the most critical test performed is potency testing, and its design merits careful consideration. For many years, potency testing of LVS has relied on parenteral vaccination of mice, which allows for assessment of residual vaccine virulence, followed by parenteral challenge with fully virulent $F$. tularensis. Ideally, future options will move away from extensive use of animals, particularly one such as this that depends on lethal challenges with BSL-3 Select Agents. Full development of potency testing should include consideration of a stressed preparation of $\triangle c l p B$ that exhibits reduced protection of animals against respiratory challenge with fully virulent $F$. tularensis SCHU S4. Relevant measurements, some of which avoid lethal challenge in vivo, may include tests that have been used to evaluate multiple different iterations of $\triangle c l p B$ over time. For example, original $\triangle c l p B$ stocks, research production lots, lyophilized lots, and stored lots have been tested for in vivo virulence in mice (IN LD ${ }_{50}$ ) and for protection against IN challenge with fully virulent $F$. tularensis, analogous to LVS potency testing (Supplementary Table S3). Clinical scores after vaccination, skin reactogenicity, bacterial genomes (Supplementary Table S4), and levels of cytokines in sera within 4 days after vaccination (Supplementary Table S5) have been monitored, all options that do not depend on lethal infections. Moreover, we have extensively explored the use of an in vitro co-culture assay that measures the ability of lymphocytes from $\Delta c l p B$ vaccinated mice or rats to control the intramacrophage growth of Francisella bacteria $[46,54,71-74]$. The degree of bacterial growth control tracks well with the degree of in vivo protection $[54,73,75]$, making this assay a potential potency assay. Only small numbers of vaccinated animals are required, and macrophages can be infected with BSL-2 strains of $F$. tularensis (including $\triangle c l p B$ and LVS), eliminating the need for BSL-3 biocontainment.

Taken together, to date, studies of $\Delta c l p B$ indicate that it is an excellent tularemia vaccine candidate. The stable, high degree of attenuation by many criteria coupled with its strong efficacy profile yield a favorable risk/benefit relationship. Moreover, commercial production at scale is feasible and economical. These factors support completing animal studies coupled with derivation of immunological correlates of vaccine-induced protection, in anticipation of proceeding to human clinical trials.

\section{Materials and Methods}

\subsection{Generation of $\triangle c l p B$ and Evaluation of Its Potential for Reversion to Wild Type}

Mutant $\Delta c l p B$ was created by deletion of 2463 out of $2580 \mathrm{bp}$ of the $c l p B$ gene using technology developed at Umea University [26]. Complementation was performed, as previously described [76]. Tests for reversion included passage of $\Delta c l p B$ through mice without intervening plating. An initial mouse was injected intraperitoneally (IP) with $\Delta c l p B$ and was euthanized on Day 3 of infection; its spleen was removed, homogenized, and re-injected into a second mouse. Mice 3-5 were similarly infected, for a total of 5 passages without intervening plating. Then, a stock of in vivo passaged $\Delta c l p B$ was prepared by plating a 1/1000 dilution of the spleen from Mouse 5 on cysteine heart agar supplemented with hemoglobin $(\mathrm{CHAH})$. The resulting bacterial lawn was used to make 
liquid suspensions that were aliquoted in small volumes and frozen at $-80^{\circ} \mathrm{C}$, as previously described [24]. Additionally, we passaged $\triangle c l p B 10$ times daily on $\mathrm{CHAH}$ agar, and then made stocks of the final passage, as above. Finally, to evaluate general stability and protein production of the bacterial mutants, we co-cultured $\triangle c l p B$ and SCHU S4 $\triangle i g l C$ on CHAH through 5 daily passages in vitro. Assuming a 2-hour doubling time, this represents at least 60 doublings, or a $>1 \times 10^{18}$-fold increase in viable bacteria over the initial inoculum. Bacteria from the fifth passage were lysed, and the presence of clpB and iglC proteins was demonstrated by mass spectrometry in approximate proportions to the quantities found in the individual mutants using previously described methods [69]

\subsection{Fermenter Growth of $\triangle c l p B$ at NRC-C}

Fermenter growth of $\triangle c l p B$ used a working volume of $22 \mathrm{~L}$ in a $30 \mathrm{~L}$ new MBR Vessel (Multiple Bioreactors and Sterile Plants AG, Zurich, Switzerland). All fermenter parameters were monitored and controlled by custom software. As proof-of-principle, we first tested large-scale $\triangle c l p B$ growth in Chamberlains defined broth (CBD) [44]. A $1 \mathrm{~mL}$ vial of a frozen stock of $\triangle c l p B$ that had been passaged 5 times in CBD was thawed and transferred to a $4 \mathrm{~L}$ baffle flask containing $1 \mathrm{~L}$ of CMB. After overnight incubation at $37^{\circ} \mathrm{C}$ with shaking, sufficient starter culture was added to a fermenter vessel containing $22 \mathrm{~L}$ of sterile CBD to give a final $\mathrm{OD}_{600}$ reading of 0.1 . At 16,19 , and $21.5 \mathrm{~h}, 150 \mathrm{~mL}$ samples were sterilely withdrawn from the fermenter, sucrose added to $20 \% w / v$, and then $1.0 \mathrm{~mL}$ aliquots were dispensed and frozen at $-80^{\circ} \mathrm{C}$. Thawed aliquots of frozen stocks were used for testing in mice. Subsequent runs were performed as above using the modified casein partial hydrolysate broth described by Karlsson et al. [77].

\subsection{Manufacturing of $\triangle c l p B$ at the $25 \mathrm{~L}$ Scale at Ology Bioservices}

To make a master cell bank, single isolated colonies of $\triangle c l p B$ were grown and selected on buffered charcoal yeast extract (BCYE) agar plates. Then, single colonies were expanded in MCPH broth. Production runs were performed under Current Good Manufacturing Procedures (cGMP) and documented with Master Batch Records. Seed strains were established by inoculating $1 \mathrm{~L}$ shake flasks containing $250 \mathrm{~mL}$ of MCPH broth. Cultures were incubated for up to $24 \mathrm{~h}$ at $37^{\circ} \mathrm{C}$, shaking at $200 \mathrm{RPM}$ until the $\mathrm{OD}_{600}$ reached $1.5 \pm 0.3$. Samples of the broth were evaluated for $\mathrm{CFU} / \mathrm{mL}$ prior to freezing. Bacteria were aliquoted as $1 \mathrm{~mL}$ in $2 \mathrm{~mL}$ cryovials. The bacteria were frozen at $<-70{ }^{\circ} \mathrm{C}$ in a solution of $1 \mathrm{~g} / \mathrm{L}$ sucrose in MCPH media. The $\triangle c l p B$ production runs were performed as follows: $\triangle c l p B$ seed strains were established by inoculating $1 \mathrm{~L}$ shake flasks containing $250 \mathrm{~mL}$ of $\mathrm{MCPH}$ broth with a single vial of the research cell bank. Cultures were incubated for up to $24 \mathrm{~h}$ at $37^{\circ} \mathrm{C}$ shaking at $200 \mathrm{RPM}$, until the $\mathrm{OD}_{600}$ reached $1.5 \pm 0.3$. The fermentation runs were performed by inoculating $24.5 \mathrm{~L}$ of $\mathrm{MCPH}$ broth with a dilution of the shake flask culture, to reach an initial $\mathrm{OD}_{600}=0.0015$ with a total of $25 \mathrm{~L}$ of MCPH broth in a $50 \mathrm{~L}$ XDR-50 fermenter (Cytiva, Marlborough, MA). The fermentation process was conducted by incubating the cells at $37^{\circ} \mathrm{C}$ for approximately $20 \mathrm{~h}$.

\subsection{Lyophilization of $\triangle \mathrm{clpB}$ Drug Product}

At NRC-C, small volumes of $\triangle c l p B(50-100 \mathrm{~mL})$ were buffer exchanged with lyophilization buffer ( $10 \mathrm{mM}$ potassium phosphate, $1 \%$ mannitol, $1 \%$ sucrose, $0.25 \%$ gelatin, $\mathrm{pH}$ 7.2.) by centrifugation, washed, and resuspended to the original volume. The GMP $\Delta c l p B$ drug product from Ology Biosciences was lyophilized by Lyophilization Technology Inc. (Warminster, PA, USA). In this case, $\triangle c l p B$ was buffer exchanged by diafiltration. Thereafter, rinsed $2 \mathrm{cc} / 13 \mathrm{~mm}$ vials were filled to a target volume of $0.50 \mathrm{~mL}$, and then lyophilized using a proprietary cycle program. Then, final vialed drug product samples were characterized for release testing. 


\subsection{Analytical Assays}

Colony forming units were determined by plating serial dilutions of $\triangle \operatorname{clpB}$ on $\mathrm{CHAH}$, $\mathrm{BCYE}$, or supplemented chocolate agar plates (as available, with equivalent results) that were incubated at $37^{\circ} \mathrm{C}$ for $48-72 \mathrm{~h}$. Antibiotic resistance was performed by plating $\triangle c l p B$ onto peptone cysteine agar plates and incubated for $72 \mathrm{~h}$ at $37^{\circ} \mathrm{C}$. Antibiotic discs containing each antibiotic were placed on the surface of the bacterial lawn and the plates incubated for $48 \mathrm{~h}$ at $37^{\circ} \mathrm{C}$. The resulting zone of complete inhibition was measured in millimeters. Endotoxin testing was performed using the Limulus Amebocyte Lysate Endosafe nexgen-PTS system, following the manufacturer's instructions (Charles River Laboratories, Wilmington, MA, USA). Whole genome sequencing was performed by Omega Bioservices (Norcross, GA, USA) and in-house by NRC-C. A PCR-based method for identification of the deletion mutant was developed using the Phusion Flash Master Mix (Thermo Scientific, Waltham, MA, USA). Two sets of primer were designed. The first set of primers were based on the sequences outside of the $c l p B$ gene and the other set included sequences from within the gene. Thirty-five cycles of the PCR reaction were completed followed by a five-minute elongation step.

\subsection{Biological Assays}

Samples of $\triangle c l p B$ generated at various stages of the product development cycle were subjected to a battery of in vivo tests in young adult female BALB/c mice. These assays included in vivo organ growth, ID and IN virulence determinations, clinical scores and skin reactogenicity, potency against ID or IN challenge with SCHU S4 or FSC033, and serum cytokine production after ID vaccination with $10^{5} \mathrm{CFU}$ (Supplementary Tables S4 and S5).

\section{Patents}

Some of the work published herein is the subject of patents US8993302B2, EP2424974B1, CA2760098C, ES2553763T3, US20210008191A1 (pending), CA3094404A1 (pending), EP3768820A1 (pending).

Supplementary Materials: The following are available online at https:/ /www.mdpi.com/article/10 .3390/pathogens10070795/s1, Table S1: FTT numbers for genes listed in Table 1; Table S2: Analytical assays for master cell bank produced at Ology; Table S3: Characterization of $25 \mathrm{~L}$ production run; Table S4: Selected cytokine and chemokine responses in serum 4 days after ID vaccination with $\sim 105 \mathrm{CFU} \Delta \mathrm{clpB}$; Table S5: $\Delta \mathrm{clpB}$ organ burdens and virulence following ID or IN challenge.

Author Contributions: Conceptualization, J.W.C., A.S., H.C.G., R.R.C., R.D.P., and K.L.E.; methodology, J.W.C., A.S., H.C.G., R.R.C., R.D.P., P.F., K.M., and K.L.E.; formal analysis, J.W.C., A.S., H.C.G., R.R.C., R.D.P., P.F., K.M., and K.L.E.; investigation, J.W.C., A.S., H.C.G., R.R.C., and R.D.P.; resources, J.W.C., A.S., H.C.G., R.R.C., R.D.P., and K.L.E.; data curation, J.W.C., A.S., H.C.G., R.R.C., R.D.P., and K.L.E.; writing-original draft preparation, J.W.C. and K.L.E.; writing-review and editing, J.W.C., A.S., H.C.G., R.R.C., R.D.P., and K.L.E.; visualization, J.W.C.; supervision, J.W.C., A.S., H.C.G., R.R.C., R.D.P., and K.L.E.; project administration, J.W.C., A.S., H.C.G., R.R.C., R.D.P., and K.L.E.; funding acquisition, J.W.C., A.S., H.C.G., R.R.C., R.D.P., and K.L.E. All authors have read and agreed to the published version of the manuscript.

Funding: This research was funded in part by a contract with the Defense Threat Reduction Agency, contract number HDTRA114-AMD2-CBM-01-2-0042 and HDTRA1-16-C-0028; intramural funding from the Center for Biologics Evaluation and Research, FDA; and Region Västerbotten (Spjutspetsmedel, VLL-582571, Centrala ALF medel, VLL-463691).

Institutional Review Board Statement: These studies were conducted according to the guidelines of the Declaration of Helsinki and approved by the Animal Care and Use Committees (ACUC) of the Center for Biologics Evaluation and Research, FDA (Animal Study Protocols 1993-2003 and 2015-2021; most recent approvals 28 November 2018 and 2 October 2018, respectively); the Ethical Committee on Animal Research, Umeå, Sweden, A99-11, and A67-14.UMEA; and the NRC-C Animal Care and Use Committee in accordance with the policies of the Canadian Council on Animal Care under animal use protocol AUP 2019-04. 
Informed Consent Statement: Not applicable.

Data Availability Statement: The data presented in this study are all available in the present article.

Acknowledgments: The authors are grateful for the technical and animal husbandry services of their respective employers. We thank our CBER colleagues, Siobhán Cowley and Anita Verma, for thoughtful reviews of the manuscript.

Conflicts of Interest: H.C.G., K.L.E., A.S., J.W.C., P.F., K.M., R.R.C., and R.D.P. declare no conflict of interest.

\section{References}

1. Sjostedt, A. Tularemia: History, epidemiology, pathogen physiology, and clinical manifestations. Ann. N. Y. Acad. Sci. 2007, 1105, 1-29. [CrossRef]

2. Oyston, P.C.; Sjostedt, A.; Titball, R.W. Tularaemia: Bioterrorism defence renews interest in Francisella tularensis. Nat. Rev. Microbiol. 2004, 2, 967-978. [CrossRef] [PubMed]

3. Desvars, A.; Furberg, M.; Hjertqvist, M.; Vidman, L.; Sjostedt, A.; Ryden, P.; Johansson, A. Epidemiology and ecology of tularemia in Sweden, 1984-2012. Emerg. Infect. Dis. 2015, 21, 32-39. [CrossRef] [PubMed]

4. Hestvik, G.; Warns-Petit, E.; Smith, L.A.; Fox, N.J.; Uhlhorn, H.; Artois, M.; Hannant, D.; Hutchings, M.R.; Mattsson, R.; Yon, L.; et al. The status of tularemia in Europe in a one-health context: A review. Epidemiol. Infect. 2015, 143, 2137-2160. [CrossRef] [PubMed]

5. Oyston, P.C. Francisella tularensis vaccines. Vaccine 2009, 27, D48-D51. [CrossRef] [PubMed]

6. Kortepeter, M.G.; Parker, G.W. Potential biological weapons threats. Emerg. Infect. Dis. 1999, 5, 523-527. [CrossRef]

7. Frischknecht, F. The history of biological warfare. Human experimentation, modern nightmares and lone madmen in the twentieth century. EMBO Rep. 2003, 4, S47-S52. [CrossRef] [PubMed]

8. Griffin, K.F.; Oyston, P.C.; Titball, R.W. Francisella tularensis vaccines. FEMS Immunol. Med. Microbiol. 2007, 49, 315-323. [CrossRef]

9. Eigelsbach, H.T.; Downs, C.M. Prophylactic effectiveness of live and killed tularemia vaccines. I. Production of vaccine and evaluation in the white mouse and guinea pig. J. Immunol. 1961, 87, 415-425.

10. Tigertt, W.D. Soviet viable Pasteurella tularensis vaccines. A review of selected articles. Bacteriol. Rev. 1962, 26, 354-373. [CrossRef]

11. Eigelsbach, H.T.; Tulis, J.J.; McGavran, M.H.; White, J.D. LIVE TULAREMIA VACCINE I: Host-Parasite Relationship in Monkeys Vaccinated Intracutaneously or Aerogenically. J. Bacteriol. 1962, 84, 1020-1027. [CrossRef] [PubMed]

12. Saslaw, S.; Eigelsbach, H.T.; Prior, J.A.; Wilson, H.E.; Carhart, S. Tularemia vaccine study. II. Respiratory challenge. Arch. Intern. Med. 1961, 107, 702-714. [CrossRef] [PubMed]

13. Saslaw, S.; Eigelsbach, H.T.; Wilson, H.E.; Prior, J.A.; Carhart, S. Tularemia vaccine study. I. Intracutaneous challenge. Arch. Intern. Med. 1961, 107, 689-701. [CrossRef] [PubMed]

14. Eigelsbach, H.T.; Hornick, R.B.; Tulis, J.J. Recent studies on live tularemia vaccine. Med. Ann. Dist. Columbia 1967, 36, 282-286.

15. Burke, D.S. Immunization against tularemia: Analysis of the effectiveness of live Francisella tularensis vaccine in prevention of laboratory-acquired tularemia. J. Infect. Dis. 1977, 135, 55-60. [CrossRef]

16. McCrumb, F.R. Aerosol Infection of Man with Pasteurella tularensis. Bacteriol. Rev. 1961, 25, 262-267. [CrossRef]

17. Hornick, R.B.; Eigelsbach, H.T. Aerogenic immunization of man with live Tularemia vaccine. Bacteriol. Rev. 1966, 30, 532-538. [CrossRef]

18. Pasetti, M.F.; Cuberos, L.; Horn, T.L.; Shearer, J.D.; Matthews, S.J.; House, R.V.; Sztein, M.B. An improved Francisella tularensis live vaccine strain (LVS) is well tolerated and highly immunogenic when administered to rabbits in escalating doses using various immunization routes. Vaccine 2008, 26, 1773-1785. [CrossRef] [PubMed]

19. Larsen, J.C.; Disbrow, G.L. Project BioShield and the Biomedical Advanced Research Development Authority: A ten year progress report on meeting U.S. preparedness objectives for threat agents. Clin. Infect. Dis. 2017, 64, 1430-1434. [CrossRef] [PubMed]

20. Popescu, S. Infection Prevention and Control: A Biodefense Measure. In Defense Against Biological Attacks: Volume I; Singh, S.K., Kuhn, J.H., Eds.; Springer International Publishing: Cham, Switzerland, 2019; pp. 145-169.

21. Conlan, J.W. Tularemia vaccines: Recent developments and remaining hurdles. Future Microbiol. 2011, 6, 391-405. [CrossRef]

22. Marohn, M.E.; Barry, E.M. Live attenuated tularemia vaccines: Recent developments and future goals. Vaccine 2013, 31, 3485-3491. [CrossRef]

23. Sunagar, R.; Kumar, S.; Franz, B.J.; Gosselin, E.J. Tularemia vaccine development: Paralysis or progress? Vaccine 2016, 6, 9-23. [CrossRef] [PubMed]

24. Twine, S.; Bystrom, M.; Chen, W.; Forsman, M.; Golovliov, I.; Johansson, A.; Kelly, J.; Lindgren, H.; Svensson, K.; Zingmark, C.; et al. A mutant of Francisella tularensis strain SCHU S4 lacking the ability to express a 58-kilodalton protein is attenuated for virulence and is an effective live vaccine. Infect. Immun. 2005, 73, 8345-8352. [CrossRef] [PubMed] 
25. Golovliov, I.; Twine, S.M.; Shen, H.; Sjostedt, A.; Conlan, W. A $\Delta$ clpB Mutant of Francisella tularensis Subspecies holarctica Strain, FSC200, Is a More Effective Live Vaccine than F. tularensis LVS in a Mouse Respiratory Challenge Model of Tularemia. PLoS ONE 2013, 8, e78671. [CrossRef]

26. Golovliov, I.; Sjostedt, A.; Mokrievich, A.; Pavlov, V. A method for allelic replacement in Francisella tularensis. FEMS Microbiol. Lett. 2003, 222, 273-280. [CrossRef]

27. Salomonsson, E.; Kuoppa, K.; Forslund, A.L.; Zingmark, C.; Golovliov, I.; Sjostedt, A.; Noppa, L.; Forsberg, A. Reintroduction of two deleted virulence loci restores full virulence to the live vaccine strain of Francisella tularensis. Infect. Immun. 2009, 77, 3424-3431. [CrossRef] [PubMed]

28. Kadzhaev, K.; Zingmark, C.; Golovliov, I.; Bolanowski, M.; Shen, H.; Conlan, W.; Sjöstedt, A. Identification of genes contributing to the virulence of Francisella tularensis SCHU S4 in a mouse intradermal infection model. PLoS ONE 2009, 4, e5463. [CrossRef] [PubMed]

29. Ryden, P.; Twine, S.; Shen, H.; Harris, G.; Chen, W.; Sjostedt, A.; Conlan, W. Correlates of protection following vaccination of mice with gene deletion mutants of Francisella tularensis subspecies tularensis strain, SCHU S4 that elicit varying degrees of immunity to systemic and respiratory challenge with wild-type bacteria. Mol. Immunol. 2013, 54, 58-67. [CrossRef]

30. Honn, M.; Lindgren, H.; Bharath, G.K.; Sjostedt, A. Lack of OxyR and KatG Results in Extreme Susceptibility of Francisella tularensis LVS to Oxidative Stress and Marked Attenuation In Vivo. Front. Cell. Infect. Microbiol. 2017, 7, 14. [CrossRef]

31. Lindgren, M.; Tancred, L.; Golovliov, I.; Conlan, W.; Twine, S.M.; Sjostedt, A. Identification of Mechanisms for Attenuation of the FSC043 Mutant of Francisella tularensis SCHU S4. Infect. Immun. 2014, 82, 3622-3635. [CrossRef] [PubMed]

32. Ozanic, M.; Marecic, V.; Lindgren, M.; Sjostedt, A.; Santic, M. Phenotypic characterization of the Francisella tularensis DeltapdpC and DeltaiglG mutants. Microbes Infect. 2016, 18, 768-776. [CrossRef]

33. Binesse, J.; Lindgren, H.; Lindgren, L.; Conlan, W.; Sjostedt, A. Roles of reactive oxygen species-degrading enzymes of Francisella tularensis SCHU S4. Infect. Immun. 2015, 83, 2255-2263. [CrossRef]

34. Forslund, A.L.; Salomonsson, E.N.; Golovliov, I.; Kuoppa, K.; Michell, S.; Titball, R.; Oyston, P.; Noppa, L.; Sjöstedt, A.; Forsberg, A. The type IV pilin, PilA, is required for full virulence of Francisella tularensis subspecies tularensis. BMC Microbiol. 2010, 10, 227. [CrossRef] [PubMed]

35. Lindgren, M.; Eneslatt, K.; Broms, J.E.; Sjostedt, A. Importance of PdpC, IglC, IglI, and IglG for modulation of a host cell death pathway induced by Francisella tularensis LVS. Infect. Immun. 2013, 81, 2076-2084. [CrossRef] [PubMed]

36. Twine, S.M.; Vinogradov, E.; Lindgren, H.; Sjostedt, A.; Conlan, J.W. Roles for wbtC, wbtI, and kdtA Genes in Lipopolysaccharide Biosynthesis, Protein Glycosylation, Virulence, and Immunogenicity in Francisella tularensis Strain SCHU S4. Pathogens 2012, 1, 12-29. [CrossRef]

37. Conlan, J.W.; Shen, H.; Golovliov, I.; Zingmark, C.; Oyston, P.C.; Chen, W.; House, R.V.; Sjöstedt, A. Differential ability of novel attenuated targeted deletion mutants of Francisella tularensis subspecies tularensis strain SCHU S4 to protect mice against aerosol challenge with virulent bacteria: Effects of host background and route of immunization. Vaccine 2010, 28, 1824-1831. [CrossRef] [PubMed]

38. Shen, H.; Harris, G.; Chen, W.; Sjostedt, A.; Ryden, P.; Conlan, W. Molecular immune responses to aerosol challenge with Francisella tularensis in mice inoculated with live vaccine candidates of varying efficacy. PLoS ONE 2010, 5, e13349. [CrossRef]

39. Allio, T. The FDA Animal Rule and its role in protecting human safety. Expert Opin. Drug Saf. 2018, 17, 971-973. [CrossRef]

40. Beasley, D.W.C.; Brasel, T.L.; Comer, J.E. First vaccine approval under the FDA Animal Rule. NPJ Vaccines 2016, 1, 16013. [CrossRef]

41. Jemski, J.V. Respiratory tularemia: Comparison of selected routes of vaccination in Fischer 344 rats. Infect. Immun. 1981, 34, 766-772. [CrossRef]

42. Wu, T.H.; Zsemlye, J.L.; Statom, G.L.; Hutt, J.A.; Schrader, R.M.; Scrymgeour, A.A.; Lyons, C.R. Vaccination of Fischer 344 rats against pulmonary infections by Francisella tularensis type A strains. Vaccine 2009, 27, 4684-4693. [CrossRef] [PubMed]

43. Ray, H.J.; Chu, P.; Wu, T.H.; Lyons, C.R.; Murthy, A.K.; Guentzel, M.N.; Klose, K.E.; Arulanandam, B.P. The Fischer 344 rat reflects human susceptibility to francisella pulmonary challenge and provides a new platform for virulence and protection studies. PLoS ONE 2010, 5, e9952. [CrossRef]

44. Chamberlain, R.E. Evaluation of Live Tularemia Vaccine Prepared in a Chemically Defined Medium. Appl. Microbiol. 1965, 13, 232-235. [CrossRef] [PubMed]

45. Hutt, J.A.; Lovchik, J.A.; Dekonenko, A.; Hahn, A.C.; Wu, T.H. The Natural History of Pneumonic Tularemia in Female Fischer 344 Rats after Inhalational Exposure to Aerosolized Francisella tularensis Subspecies tularensis Strain SCHU S4. Am. J. Pathol. 2017, 187, 252-267. [CrossRef]

46. De Pascalis, R.; Hahn, A.; Brook, H.M.; Ryden, P.; Donart, N.; Mittereder, L.; Frey, B.; Wu, T.H.; Elkins, K.L. A panel of correlates predicts, vaccine-induced protection of rats against respiratory challenge with virulent Francisella tularensis. PLoS ONE 2018, 13, e0198140. [CrossRef]

47. Marshall, L.E.; Nelson, M.; Davies, C.H.; Whelan, A.O.; Jenner, D.C.; Moule, M.G.; Denman, C.; Cuccui, J.; Atkins, T.P.; Wren, B.W.; et al. An O-Antigen Glycoconjugate Vaccine Produced Using Protein Glycan Coupling Technology Is Protective in an Inhalational Rat Model of Tularemia. J. Immunol. Res. 2018, 2018, 8087916. [CrossRef] [PubMed]

48. Vinogradov, E.; Perry, M.B.; Conlan, J.W. Structural analysis of Francisella tularensis lipopolysaccharide. Eur. J. Biochem. 2002, 269, 6112-6118. [CrossRef] [PubMed] 
49. Mulligan, M.J.; Stapleton, J.T.; Keitel, W.A.; Frey, S.E.; Chen, W.H.; Rouphael, N.; Edupuganti, S.; Beck, A.; Winokur, P.L.; El Sahly, H.M.; et al. Tularemia vaccine: Safety, reactogenicity, "Take" skin reactions, and antibody responses following vaccination with a new lot of the Francisella tularensis live vaccine strain-A phase 2 randomized clinical Trial. Vaccine 2017, 35, 4730-4737. [CrossRef]

50. Cherwonogrodzky, J.W.; Knodel, M.H.; Spence, M.R. Increased encapsulation and virulence of Francisella tularensis live vaccine strain (LVS) by subculturing on synthetic medium. Vaccine 1994, 12, 773-775. [CrossRef]

51. Sandstrom, G.; Sjostedt, A.; Johansson, T.; Kuoppa, K.; Williams, J.C. Immunogenicity and toxicity of lipopolysaccharide from Francisella tularensis LVS. FEMS Microbiol. Immunol. 1992, 5, 201-210. [CrossRef] [PubMed]

52. Eneslatt, K.; Rietz, C.; Ryden, P.; Stoven, S.; House, R.V.; Wolfraim, L.A.; Tärnvik, A.; Sjöstedt, A. Persistence of cell-mediated immunity three decades after vaccination with the live vaccine strain of Francisella tularensis. Eur. J. Immunol. 2011, 41, 974-980. [CrossRef]

53. Eneslatt, K.; Golovliov, I.; Ryden, P.; Sjostedt, A. Vaccine-Mediated Mechanisms Controlling Replication of Francisella tularensis in Human Peripheral Blood Mononuclear Cells Using a Co-culture System. Front. Cell. Infect. Microbiol. 2018, 8, 27. [CrossRef] [PubMed]

54. Lindgren, H.; Eneslatt, K.; Golovliov, I.; Gelhaus, C.; Ryden, P.; Wu, T.; Sjöstedt, A. Vaccine-Mediated Mechanisms Controlling Francisella tularensis SCHU S4 Growth in a Rat Co-Culture System. Pathogens 2020, 9, 338. [CrossRef]

55. Ohtake, S.; Martin, R.A.; Saxena, A.; Lechuga-Ballesteros, D.; Santiago, A.E.; Barry, E.M.; Truong-Le, V. Formulation and stabilization of Francisella tularensis live vaccine strain. J. Pharm. Sci. 2011, 100, 3076-3087. [CrossRef]

56. Staples, J.E.; Kubota, K.A.; Chalcraft, L.G.; Mead, P.S.; Petersen, J.M. Epidemiologic and molecular analysis of human tularemia, United States, 1964-2004. Emerg. Infect. Dis. 2006, 12, 1113-1118. [CrossRef] [PubMed]

57. Overholt, E.L.; Tigertt, W.D.; Kadull, P.J.; Ward, M.K.; Charkes, N.D.; Rene, R.M.; Salzman, T.E.; Stephens, M. An analysis of forty-two cases of laboratory-acquired tularemia. Treatment with broad spectrum antibiotics. Am. J. Med. 1961, 30, 785-806. [CrossRef]

58. Matyas, B.T.; Nieder, H.S.; Telford, S.R., III. Pneumonic tularemia on Martha's Vineyard: Clinical, epidemiologic, and ecological characteristics. Ann. N. Y. Acad. Sci. 2007, 1105, 351-377. [CrossRef] [PubMed]

59. Feodorova, V.A.; Sayapina, L.V.; Corbel, M.J.; Motin, V.L. Russian vaccines against especially dangerous bacterial pathogens. Emerg. Microbes Infect. 2014, 3, e86. [CrossRef]

60. Ma, Y.; Vigouroux, G.; Kalantari, Z.; Goldenberg, R.; Destouni, G. Implications of Projected Hydroclimatic Change for Tularemia Outbreaks in High-Risk Areas across Sweden. Int. J. Environ. Res. Public Health 2020, 17, 6786. [CrossRef] [PubMed]

61. Hennebique, A.; Boisset, S.; Maurin, M. Tularemia as a waterborne disease: A review. Emerg. Microbes Infect. 2019, 8, 1027-1042. [CrossRef]

62. Singh, A. Eliciting B cell immunity against infectious diseases using nanovaccines. Nat. Nanotechnol. 2021, 16, 16-24. [CrossRef]

63. Vetter, V.; Denizer, G.; Friedland, L.R.; Krishnan, J.; Shapiro, M. Understanding modern-day vaccines: What you need to know. Ann. Med. 2018, 50, 110-120. [CrossRef] [PubMed]

64. Sandstrom, G. The tularaemia vaccine. J. Chem. Technol. Biotechnol. 1994, 59, 315-320. [CrossRef] [PubMed]

65. Vosti, K.L.; Ward, M.K.; Tigertt, W.D. Agar gel precipitin analyses in laboratory-acquired tularemia. J. Clin. Investig. 1962, 41, 1436-1445. [CrossRef] [PubMed]

66. El Sahly, H.M.; Atmar, R.L.; Patel, S.M.; Wells, J.M.; Cate, T.; Ho, M.; Guo, K.; Pasetti, M.F.; Lewis, D.E.; Sztein, M.B.; et al. Safety, reactogenicity and immunogenicity of Francisella tularensis live vaccine strain in humans. Vaccine 2009, 27, 4905-4911. [CrossRef]

67. Elkins, K.L.; Kurtz, S.L.; De Pascalis, R. Progress, challenges, and opportunities in Francisella vaccine development. Expert Rev. Vaccines 2016, 15, 1183-1196. [CrossRef]

68. Twine, S.M.; Shen, H.; Kelly, J.F.; Chen, W.; Sjostedt, A.; Conlan, J.W. Virulence comparison in mice of distinct isolates of type A Francisella tularensis. Microb. Pathog. 2006, 40, 133-138. [CrossRef]

69. Twine, S.; Shen, H.; Harris, G.; Chen, W.; Sjostedt, A.; Ryden, P.; Conlana, W. BALB/c mice, but not C57BL/6 mice immunized with a $\Delta \mathrm{clpB}$ mutant of Francisella tularensis subspecies tularensis are protected against respiratory challenge with wild-type bacteria: Association of protection with post-vaccination and post-challenge immune responses. Vaccine 2012, 30, 3634-3645.

70. Chen, W.; Shen, H.; Webb, A.; KuoLee, R.; Conlan, J.W. Tularemia in BALB/c and C57BL/6 mice vaccinated with Francisella tularensis LVS and challenged intradermally, or by aerosol with virulent isolates of the pathogen: Protection varies depending on pathogen virulence, route of exposure, and host genetic background. Vaccine 2003, 21, 3690-3700.

71. Bosio, C.M.; Elkins, K.L. Susceptibility to secondary Francisella tularensis live vaccine strain infection in B-cell-deficient mice is associated with neutrophilia but not with defects in specific T-cell-mediated immunity. Infect. Immun. 2001, 69, 194-203. [CrossRef]

72. Bradford, M.K.; Elkins, K.L. Immune lymphocytes halt replication of Francisella tularensis LVS within the cytoplasm of infected macrophages. Sci. Rep. 2020, 10, 12023. [CrossRef] [PubMed]

73. De Pascalis, R.; Chou, A.Y.; Ryden, P.; Kennett, N.J.; Sjostedt, A.; Elkins, K.L. Models derived from in vitro analyses of spleen, liver, and lung leukocyte functions predict vaccine efficacy against the Francisella tularensis Live Vaccine Strain (LVS). mBio 2014, 5, e00936. [CrossRef] [PubMed] 
74. Golovliov, I.; Lindgren, H.; Eneslatt, K.; Conlan, W.; Mosnier, A.; Henry, T.; Sjöstedt, A. An In Vitro Co-culture Mouse Model Demonstrates Efficient Vaccine-Mediated Control of Francisella tularensis SCHU S4 and Identifies Nitric Oxide as a Predictor of Efficacy. Front. Cell. Infect. Microbiol. 2016, 6, 152. [CrossRef] [PubMed]

75. De Pascalis, R.; Chou, A.Y.; Bosio, C.M.; Huang, C.Y.; Follmann, D.A.; Elkins, K.L. Development of functional and molecular correlates of vaccine-induced protection for a model intracellular pathogen, F. tularensis LVS. PLoS Pathog. 2012, 8, e1002494. [CrossRef]

76. Lindgren, H.; Honn, M.; Golovlev, I.; Kadzhaev, K.; Conlan, W.; Sjostedt, A. The 58-kilodalton major virulence factor of Francisella tularensis is required for efficient utilization of iron. Infect. Immun. 2009, 77, 4429-4436. [CrossRef]

77. Karlsson, J.; Prior, R.G.; Williams, K.; Lindler, L.; Brown, K.A.; Chatwell, N.; Hjalmarsson, K.; Loman, N.; Mack, K.A.; Pallen, M.; et al. Sequencing of the Francisella tularensis strain SCHU 4 genome reveals the shikimate and purine metabolic pathways, targets for the construction of a rationally attenuated auxotrophic vaccine. Microb. Comp. Genom. 2000, 5, 25-39. [CrossRef] 